\title{
TITLE: Subaqueous cryptodome eruption, hydrothermal activity and related seafloor morphologies on the andesitic North Su volcano.
}

\author{
Authorship: Janis Thal ${ }^{1 *}$, Maurice Tivey ${ }^{2}$, Dana R. Yoerger ${ }^{2}$, Wolfgang Bach ${ }^{1}$ \\ ${ }^{1}$ MARUM, University of Bremen, 28359 Bremen, Germany \\ ${ }^{2}$ Woods Hole Oceanographic Institution, Woods Hole, MA 02543, USA \\ ${ }^{*}$ corresponding author: \\ Janis Thal \\ Email: ja_th@uni-bremen.de \\ Phone: +4942121846405
}




\section{Abstract}

North $\mathrm{Su}$ is a double-peaked active andesite submarine volcano located in the eastern Manus Basin of the Bismarck Sea that reaches a depth of $1154 \mathrm{~m}$. It hosts a vigorous and varied hydrothermal system with black and white smoker vents along with several areas of diffuse venting and deposits of native sulfur. Geologic mapping based on ROV observations from 2006 and 2011 combined with morphologic features identified from repeated bathymetric surveys in 2002 and 2011 document the emplacement of a volcanic cryptodome between 2006 and 2011. We use our observations and rock analyses to interpret an eruption scenario where highly viscous, crystal-rich andesitic magma erupted slowly into the water-saturated, gravel-dominated slope of North Su. An intense fragmentation process produced abundant blocky clasts of a heterogeneous magma (olivine crystals within a rhyolitic groundmass) that only rarely breached through the clastic cover onto the seafloor. Phreatic and phreatomagmatic explosions beneath the seafloor cause mixing of juvenile and pre-existing lithic clasts and produce a volcaniclastic deposit. This volcaniclastic deposit consists of blocky, non-altered clasts next, variably (1-100 \%) altered clasts, hydrothermal precipitates and crystal fragments. The usually applied parameters to identify juvenile subaqueous lava fragments, i.e. fluidal shape or chilled margin, were not applicable to distinguish between pre-existing non-altered clasts and juvenile clasts. This deposit is updomed during further injection of magma and mechanical disruption. Gas-propelled turbulent clast-recycling causes clasts to develop variably rounded shapes. An abundance of blocky clasts and the lack of clasts typical for the contact of liquid lava with water is interpreted to be the result of a cooled, high-viscosity, crystal-rich magma that failed as a brittle solid upon stress. The high viscosity allows the lava to form blocky and short lobes. The pervasive 
volcaniclastic cover on North Su is partly cemented by hydrothermal precipitates. These hydrothermally-cemented breccias, crusts and single pillars show that hydrothermal circulation through a thick layer of volcaniclastic deposits can temporarily increase slope stability through precipitation and cementation.

\section{Introduction}

More than 32,000 seamounts worldwide rise $>750$ meters above the regional seafloor that have been identified by satellite altimetry and ship-based bathymetry. Most of which are believed to be of volcanic origin (Wessel, 2001; Hillier and Watts, 2007). Despite the enormous number of seamounts, only a few have been studied in detail and little is known about their formation. Over the past decade, technological advances in seafloor imaging and in situ observations, in concert with a number of dedicated research cruises, have increased our knowledge of, and perspective on, submarine volcanism and the architecture of submarine volcanoes (e.g. Wright et al., 2003; Embley et al., 2006; Carey and Sigurdsson, 2007; Chadwick Jr. et al., 2008; Allen and McPhie, 2009; Leat et al., 2010; Schipper et al., 2010; Clague et al., 2011; Deardorff et al., 2011; Resing et al., 2011). Seafloor exploration, particularly, by remotely operated vehicles (ROV) and repeated bathymetric surveys has allowed detailed documentation of the temporal changes in seafloor morphology and associated volcanic activity (e.g. Wright et al., 2003; Embley et al., 2006; Carey and Sigurdsson, 2007; Chadwick Jr. et al., 2008; Clague et al., 2011; Watts et al., 2012).

In contrast to mid ocean ridges, volcanic activity in arc settings is clearly highly diverse in space, time and composition and featuring variable eruption styles from explosive to 
effusive dome emplacement (e.g. Embley et al., 2006; Carey and Sigurdsson, 2007; Allen et al., 2010; Resing et al., 2011). As an example, volcanoes along the TongaKermadec-arc have been important in understanding the eruption products of arc-related submarine volcanism and the architecture of such volcanoes (de Ronde et al., 2006; Chadwick et al., 2008; Clague et al., 2011; Watts et al., 2012). In particular, Brothers volcano in the Kermadec arc has been studied in detail and provides an especially important example of the surface expressions formed by volcanic eruptions, along with processes associated with extensive hydrothermal activity and slope collapse (de Ronde et al., 2011).

This paper presents a broad systematic analysis of seafloor structures of the active andesite North Su submarine volcano, the central edifice of the SuSu Knolls, based on two geologic mapping campaigns and sets the stage for future in-depth volcanology studies. The SuSu knolls formed in a back-arc-volcanic system in the eastern Manus Basin of the Bismarck Sea. The associated hydrothermal setting is the submarine equivalent of terrestrial high-sulfidation $\mathrm{Cu}-\mathrm{Au}$ mineralization deposits (Binns et al., 1997; Moss and Scott, 2001; Yeats et al., 2008). The North Su volcano hosts an active multi-component hydrothermal system which is a potential analog for the highly prospective volcanic hosted massive sulfide deposits (Hedenquist and Lowenstern, 1994; de Ronde et al., 2003, 2011; Hannington et al., 2005). The host rock composition combined with the entrainment of volatile species from the magmatic system facilitates the enrichment of economically important metals such as copper, gold and zinc (e.g. Sangster, 1980; Herzig, 1999; lizasa, 1999; Hannington et al., 2005, 2011; Mosier et al., 2009). The bathymetry and geological observations of North Su volcano collected from 
three cruises in 2002, 2006 and 2011, combined with a Geographical Information Systems (GIS) database of AUV-based micro-bathymetry as well as video recordings, rock analyses and temperature measurements are used to understand the recent volcanic and hydrothermal activity of North Su volcano.

\section{Regional Geology}

The Manus Basin is a rapidly opening back-arc basin in the southeastern Bismarck Sea that is associated with the northward subduction of the Solomon Sea plate at the New Britain Trench (Taylor, 1979; Taylor et al., 1994; Martinez and Taylor, 1996, 2003) (Fig. 1). A band of active seismicity called the Bismarck Sea Seismic Lineation (BSSL) effectively divides the basin into the North and South Bismarck Plates (Tregoning et al., 1998). The BSSL is defined by left-lateral transform faults and small spreading segments including the Manus Spreading Center (Fig. 1). Rapid clockwise rotation ( $8^{\circ}$ $\mathrm{Ma}^{-1}$ ) of the South Bismarck Plate (Tregoning et al., 1999) results in an asymmetric spreading of the North and South Bismarck Plate, which causes an eastward propagation of the BSSL.

In the central Manus Basin, MORB-like lava at the Manus Spreading Center (MSC, Fig.1) indicates true seafloor spreading (Martinez and Taylor, 1996; Sinton et al., 2003). In contrast, remnant mid-Cenozoic island arc crust (Coleman and Packham, 1976; Falvey and Pritchard, 1982; Kroenke and Rodda, 1984) is rifted in the eastern part of the basin creating a series of sigmoidal neovolcanic ridges (the South East Ridges; SER) and solitary volcanoes with lava compositions ranging from basalt to rhyodacite (Binns and Scott, 1993; Sinton et al., 2003). The $\sim 70 \mathrm{~km}$ long SER volcanic zone is situated at 
the easternmost tip of the BSSL and, due to the asymmetric spreading, exhibit the highest spreading rates in the Manus Basin (up to $137.5 \mathrm{~mm} \mathrm{a}^{-1}$; (Tregoning et al., 1998, 1999; Tregoning, 2002)).

Two left-lateral transform faults (the Djaul and Weitin transforms, Fig. 1 and 2) border the SER (Martinez and Taylor, 1996) and create an intra-transform configuration that produces a stepwise en-echelon alignment of volcanic ridges and seamounts. Several hydrothermal vent areas, including PACManus, Desmos and SuSu Knolls have been discovered at the SER (Binns and Scott, 1993; Auzende et al., 1996, 2000; Gamo et al., 1997; Hashimoto et al., 1999; Tivey et al., 2006; Bach et al., 2011; Thal et al., 2014). The accumulation of polymetallic sulfides in these areas has been considered a modern analog of ancient Volcanic Massive Sulfide (VMS) deposits mined on land (e.g. Binns and Scott, 1993; Petersen et al., 2003; Yeats et al., 2014).

The SuSu Knolls area comprises three volcanic edifices (South Su, North Su and Suzette, Fig. 3 and 4) situated on the NNW striking Tumai Ridge (Moss and Scott, 2001). In 1993, the PACMANUS II cruise detected a strong water column plume anomaly over the SuSu Knolls area (Binns and Parr, 1993) and several subsequent cruises including the 1996 PACMANUS III, 1997 PACMANUS IV, and 2000 Binatang cruises went on to document the SuSu Knolls hydrothermal district using video sled and dredge surveys (Binns et al., 1997; Yeats et al., 2014). More recently, the area has been visited by several expeditions for commercial economic exploration (e.g. Crowhurst and Lowe, 2011) as well as by international research cruises that focused on the 
hydrothermal fluid chemistry, mineral deposition, biology and geology (Auzende et al., 2000; Tivey et al., 2006; Bach et al., 2011).

Susu Knolls lies at the intersection of the Tumai Ridge with Bugave Ridge, a NEtrending extensional rift structure that overshoots the Weitin transform (Fig. 3). Both ridges are comprised of lavas with compositions ranging from basaltic to dacitic (Binns and Scott, 1993; Moss, 2000). The SuSu Knolls hydrothermal area hosts three hydrothermal fields named equivalent to the volcanic structures: Suzette, North Su and South Su. Suzette is the northernmost edifice of SuSu Knolls that hosts an active hydrothermal field along with a deposit of sulfide mineralization that is now the subject of commercial interest by Nautilus Minerals Inc. (Solwara-1 prospect: Golder Associates Pty Ltd, 2012). North Su, the central edifice of SuSu Knolls, is a conical-shaped volcanic edifice rising from $1600 \mathrm{~m}$ to $1154 \mathrm{~m}$ water depth with slopes generally ranging from $25^{\circ}$ to $30^{\circ}$ (Fig. 4). The seafloor to the NE and SW of North Su appears to be a graben structure (Fig. 3). The North Su hydrothermal field hosts a range of hydrothermal vent sites ranging from high temperature black smoker chimneys at the summit to diffuse and distributed venting on the slopes including sulfur fields. South Su, $1 \mathrm{~km}$ south of North $\mathrm{Su}$, is a more degraded conical constructional volcanic edifice that has an arcuate remnant of a summit region, possibly the result of sector collapse to the northeast. South Su summit reaches only $1320 \mathrm{~m}$ water depth and its hydrothermal field hosts a few high temperature hydrothermal vent sites, but mostly diffuse/shimmering hydrothermal activity along with inactive sulfides and sulfide debris from collapsed chimneys (Tivey et al., 2006). 


\section{Methods}

The initial surveys of North Su between 1997 and 2000 were restricted to low resolution photo sled surveys and dredges (Binns et al., 1997; Yeats et al., 2014). In 2006, the Woods Hole Oceanographic Institution (WHOI) commenced the Magellan-06 research expedition in collaboration with Nautilus Minerals. This provided more detailed information about the geologic setting and hydrothermal system of the SuSu Knolls region (Tivey et al., 2006). High-resolution bathymetry recorded by the autonomous underwater vehicle (AUV) ABE was supplemented by detailed rock and fluid sampling by the remotely-operated vehicle (ROV) Jason-2. The high-resolution ABE bathymetry from Magellan-06 combined with video recordings from three ROV Jason-2 dives (\#221, $223,227)$ allow us to document the first detailed, georeferenced mapping of the volcanic and hydrothermal structures at North Su.

In 2011, a follow-up cruise (RV Sonne cruise SO216; Bach et al., 2011) focused on detailed sampling of hydrothermal fluids and biota at SuSu Knolls. An additional twelve ROV dives, using the ROV MARUM Quest4000, were completed over the North Su summit area, allowing us to confirm the meter-scale reliability of the AUV ABE maps generated during the Magellan-06 expedition. The dense data coverage generated by the 12 ROV dives over an area of $\sim 140,000 \mathrm{~m}^{2}$ expanded the mapping from 2006 and allowed us to create a comprehensive dataset of the spatial distribution of volcanic and hydrothermal structures at North Su.

Because high resolution AUV bathymetry was not conducted in 2011, a detailed, areawide comparison of changes in seafloor morphology was not straightforward. Only areas covered by ROV observation can be compared against the seafloor topography five 
years earlier. As shown in the map of 2011 data (Fig. 5b), the areal extent of some lithologies are better constrained and some new structures were mapped. Slight differences between the contours of mapped lithologies (Fig. 5a, b) are also caused by small uncertainties in ROV navigation. Overall, however, ROV MARUM Quest4000 depth values were found to be consistent with 2006 ROV Jason-2 data as well as with the AUV ABE bathymetry from 2006.

Additionally, ship-based swath bathymetry from the SO-166 cruise (Herzig et al., 2002) was used to track morphologic changes on a regional scale. Examples of seafloor structures mapped in this study are shown in Figures 6 and 7. Sample SO-216-51-ROV10 (Fig. 6 j) from the South Peak cryptodome summit was taken with an ROV-mounted shovel that could be closed after sampling. The lithologic terms used in this study are mainly descriptive and we have tried to avoid terms with genetic connotations. The lithologic terms used in this study are aligned to the terminology of volcaniclastic deposits by McPhie et al. (1993). We describe deposits consisting of any fragmental volcanic material of any origin up to pebble size $(4 \mathrm{~mm})$ as volcaniclastic deposits or debris only, with size, shape and particle description where possible. Bigger clasts are either named according to the chosen terminology or described with a metric size. We mapped all intrusive or extrusive volcanic outcrops as coherent volcanic rocks (e.g. Fig. 5 and 6).

\section{Results}

During the 2011 cruise (SO-216) it was clear, both from ship-based multibeam surveys and near bottom observations, that an eruption had taken place at North Su, which had significantly changed the morphology, i.e. partial updoming, of the North Su volcano. 
Below we first discuss the detailed observations of the northern part of North Su that remained unchanged between 2006 and 2011 and then the subsequent observations of the southern part of North Su that changed dramatically.

\subsection{Unchanged volcanic morphology and hydrothermal activity in 2006 and 2011}

North Su volcano rises about $450 \mathrm{~m}$ above the surrounding seafloor reaching a summit at $1154 \mathrm{~m}$ and exhibits a conical edifice in the ship-based bathymetry (Fig. 3). The mean slope calculated from ship-based bathymetry is between $25^{\circ}$ and $30^{\circ}$ (Fig. 4 b). This shape is consistent with the AUV bathymetry data below $1350 \mathrm{~m}$, but at shallower water depths the edifice is more complex with slopes exceeding $30^{\circ}$ in many places, including vertical cliffs near the summit. Geologic mapping of North Su is generally limited to the uppermost $\sim 140 \mathrm{~m}$ of the volcano where hydrothermal vents are present.

The 2006 AUV bathymetry (Fig. 4 and 5a) reveal that the summit of North Su is doublepeaked with the main summit North Peak, reaching $1154 \mathrm{mbsl}$, and a South Peak to the south, reaching $1225 \mathrm{mbsl}$ and resembling a crater in 2006. The area of South Peak has changed between 2006 and 2011 and is therefore described in the next chapter. North Peak has a crescent-shaped crest, which opens southward and hosts active black smoker vent sites (\#1 and \#2, Fig. 5a) only along the N-S trending western site of the crest. At vent site $\# 1$, the active chimneys reached $314^{\circ} \mathrm{C}$ in 2011 and are located on top of a broad convex shield of sulfide-cemented flange-like material that has warm fluid (Tmax. $68^{\circ} \mathrm{C}, 2006$ ) leaking out from under it. Site \#2 is a cluster of chimneys (up to 11 $\mathrm{m}$ high with $\operatorname{Tmax} .302^{\circ} \mathrm{C}$ in 2006) with beehives and multiple orifices. A few inactive chimneys were mapped between sites \#1 and \#2. Shimmering water emanating from the 
seafloor along the crest indicated diffuse venting. . Besides the sulfide chimneys, the seafloor of North Peak is covered by a unconsolidated fine volcaniclastic deposit and scattered $>10 \mathrm{~cm}$ volcanic clasts. The fine volcaniclastic deposit is a mixture of highly to non-altered volcanic rocks and fractured crystals with a dominant grain size of $-<4 \mathrm{~mm}$. In places the volcaniclastic deposit is cemented by hydrothermal barite-sphalerite cement that forms slabs. Pyrite and other hydrothermal precipitates occur as well (Yeats et al., 2014). No quenched (i.e. fresh) glass shards or pumice fragments were found. Vent site \#3 is located just below the crest on the western slope at $1220 \mathrm{~m}$ water depth in very steep terrain consisting of volcaniclastic material that forms near-vertical cliffs and pillars. Black-smoker fluids discharge through these steep walls with temperatures up to $325^{\circ} \mathrm{C}$, and show visual evidence (pulse-like fluid discharge and flashing at the vent orifices) of phase separation.

Outcrops of coherent volcanic rocks on North Peak are limited to the northern and northeastern slope (Fig. 5). Northeast of the summit, a vertical volcanic spine (Fig. 6, d) protrudes out of the ridgeline that is covered by volcaniclastic deposits. On the ridge-line downslope towards vent site \#4 outcrops expose strongly fissured, stubby and blocky plagioclase-olivine phyric andesitic lava (e.g. Fig. 6 a, b) surrounded by sharp-edged, blocky gravel. Vent site \#4 (Tmax: $32^{\circ} \mathrm{C}$ ) is diffuse with macro fauna and clear fluids seeping through the gravel and discharge through fissures in the lava.

The slope between vent site \#4 and site \#5 is mainly covered by gravel and fine volcaniclastic deposits. At vent site \#5, grey colored fluids with temperatures $<240^{\circ} \mathrm{C}$ vent through a hydrothermally cemented ledge of altered volcanic clasts. Upslope and 
south from vent site \#5, a cliff face cut by erosional gullies shows that the slope here consists of volcaniclastic deposits, similar to the cliffs at vent site \#3, but with native sulfur flanges protruding from in between the clasts. Vertical edifices, up to $16 \mathrm{~m}$ high, constructed of clastic material often show signs of hydrothermal activity in the form of white staining, void-fills of native sulfur, and/or bacterial mats. These structures exist around North Peak except for the northeastern part, where coherent volcanic rocks outcrop (Fig. 5a; 7h, i).

The eastern slope is dominated by steep but continuous ridges made up of angular, volcanic gravel (several $\mathrm{cm}$ to $\mathrm{dm}$ diameter) covered by fine volcaniclastic deposits and a few, small vertical outcrops. Turtle shell cracks on these outcrops and jigsaw-fit clasts on the ridges indicate cooling fractures.

The western slopes of South Crater were generally covered with fine volcaniclastic deposits and littered with clasts up to several 10's of $\mathrm{cm}$ in diameter. The south and east slopes of South Crater were not investigated in 2006.

\subsection{Changes in volcanic morphology and hydrothermal activity between 2006 and}

\section{1}

The repeat 2011 survey of North Peak over its northern, western and eastern slopes showed the same lithology and morphology as mapped in 2006. However, the area of

South Peak changed dramatically between 2006 and 2011 that also affected the southern slope of North Peak. 
The southern edge of the North Peak summit is defined by a 14-m high cliff, south of vent site \#2 (Fig. 5), made up of cemented volcaniclastic deposits (Fig. 7 f) that remained the same in 2006 and 2011, although the abundance of hydrothermal staining and putative microbial mats had increased in 2011. In both years no black smoker vents were observed south of that cliff. In 2006, from the base of this cliff, a moderate slope $\left(25^{\circ}\right)$, covered with fine volcaniclastic debris and fewer gravel, extends downslope southwards into the South Peak crater (Fig. 5a). The slope was bordered to the east and west by cliffs, pillars or ridges, all made up of cemented volcaniclastic debris. On the ridge bordering the moderate slope to the east, white smoker vents were mapped in 2006, but not sampled. In 2011, the hydrothermal activity along this ridge had ceased and the ridge itself resembled an en-echelon alignment of pillars (Fig. $7 \mathrm{~h}$ ) rather than a continuous ridge, as observed in 2006. In 2011 further inspections of these pillars confirmed a robust buildup of volcaniclastic debris and the absence of coherent volcanic rocks. The clasts are $1 \mathrm{~mm}$ to several cm's in diameter and dominantly blocky. Flanges of solidified native sulfur appear to have oozed between the clasts, similar to what was observed on the north slope of North Peak.

In 2011, the moderate slope between North and South Peak hosts white smoker vent sites \#7 and \#8. Vent site \#7 was a small site with a maximum venting temperature of $71^{\circ} \mathrm{C}$ in 2006 and not further inspected. In 2011, this site has grown and was named Sulfur Candle (\#7, Fig. 7 a; Fig. 5 b) because of copious amounts of sulfur that had formed small chimneys or had accumulated in meter-sized knolls. The release of bubbles of liquid $\mathrm{CO}_{2}$ was common and $\mathrm{CO}_{2}$-clathrate formation could be confirmed visually by an improvised bubble-catching device. 
White smoker vent site \#8 (Fig. 5b) extends towards the west and marks the boundary of North and South Peak. Very poor visibility inside the white smoker vent site limited the video mapping abilities, but zones of extensive altered rocks could be identified. This extensive white smoker vent site did not exist in 2006, although scattered white smoker activity was observed in this area (vent site \#6) in 2006. Vent site \#6 was a cluster of white smoker vents in 2006 where fluids discharged through the gravel-covered slope (Fig. 5a). The sampled fluids were exceptionally acidic, ranging from $\mathrm{pH}$-values as low as 0.87 (Seewald et al., 2015). Fluid temperatures of up to $284^{\circ} \mathrm{C}$ were measured, but the most acidic fluid was $220^{\circ} \mathrm{C}$. The temperature-probe, after sticking it into the gravel next to the vent site, was covered with native sulfur, indicating that the gravel-covered slope around the vents is saturated with liquid sulfur. In 2006, close to vent site \#6, a massive NNE-trending volcanic outcrop featured remarkable flanges of native sulfur that appeared to have oozed out of the massive rock. In 2011 the area of vent site \#6 was covered by $>50 \mathrm{~m}$ of volcanic material.

During the two weeks of survey work in 2011 white smoker hydrothermal activity was highly variable and shifting between vent site \#8 and Sulfur Candle changing between being practically inactive at \#8 with vigorously venting boiling sulfur at Sulfur Candle and vice versa 12 days later (Fig. 9). These fluctuations in activity are not expressed across the entire North Su hydrothermal area. Rather, they appear to reflect shifts in the locations of vigorous discharge.

At the southern edge of Sulfur Candle, remnants of the South Peak crater rim still exists with the same morphology as observed in 2006 (Fig. 5 b). The South Peak crater in 2006 had a diameter of $\sim 80 \mathrm{~m}$ with a max. depth of $13 \mathrm{~m}$ and a rim that terminates into 
the southern moderate slope of North Peak. The crater rim was visited only once in 2006, when loose, fine volcaniclastic debris with thin, broken hydrothermal crusts and widespread occurrence of white bacterial mats were observed. In 2011, the rim is still covered by fine volcaniclastic deposits, but in some areas the rim is broken and the interior shows abundant blocky volcanic clasts up to several $\mathrm{cm}$ in size within native sulfur deposits (Fig. 6 f). However, no bacterial mats existed anymore along the remnants of the 2006 crater rim in 2011. Following the remnant crater rim to the south, increasing numbers of native sulfur flows appear on the outside rim and protrude out from the slope (Fig. $7 \mathrm{~g}$ ). In some parts, the sulfur flow structures are still preserved. The eastern and southern slopes below the sulfur flows are littered with broken sulfur slab scree as well as gravel of fresh and altered volcanic rocks lying on top of a bed of fine volcaniclastic deposits (in 2011).

Between 2006 and 2011 a major change in volcanic morphology occurred in the area of the 2006 South Peak crater. In 2011, a new volcanic crypto dome, hereinafter referred to as South Peak cryptodome (Fig. $6 \mathrm{c}, \mathrm{e}, \mathrm{g}, \mathrm{h}, \mathrm{i}, \mathrm{j}$, and $7 \mathrm{c}$ ), with its crest $\sim 50 \mathrm{~m}$ west of the 2006 South Peak crater center, covers most of the crater and its western slope with the white smoker vent site \#6, which is buried under $>50 \mathrm{~m}$ of volcanic material (Fig. 5 b).

The slopes of recently erupted South Peak cryptodome expose predominantly unconsolidated, variably blocky clasts up to $>10 \mathrm{~cm}$ in diameter (Fig. $6 \mathrm{e} ; 7 \mathrm{c}$ ), similar to the clasts sizes at North Peak. The upper $20 \mathrm{~m}$ of the new cryptodome are dominated by volcanic sand- and granules (Fig. $6 \mathrm{~g}, \mathrm{~h}$, i) with minor pebbles and cobbles. Only occasionally are clasts up to several tens of centimeters in diameter. On the west and southwest slopes, below the uppermost $20 \mathrm{~m}$ of South Peak cryptodome fresh volcanic 
rocks occasionally crop out of the mainly gravel-covered slope. These outcrops are blocky, stubby, fissured and similar to outcrops on the northeastern slope of North Peak. One volcanic outcrop revealed columnar joints (Fig. 6 c). Another was a lava lobe with a rounded surface (Fig. 6 e). White staining occurs mainly on the southwestern slope, whereas the western slope is almost entirely covered by an unidentified orange coating, likely a Fe-oxyhydroxide. Two zones of diffuse fluid discharge, elongated in shape and oriented radially with the center of South Peak, were observed - the larger one is shown on the map in Figure 5 b (Fig. 7 c). The hydrothermal fluids deposit native sulfur and other unidentified phases as a matrix between the loose rocks.

The South Peak cryptodome crest can be divided into two zones based on the morphology: a plateau (Fig. $6 \mathrm{~g}$ ) and a crater group. A smooth plateau, which is a littered with clasts dominantly $<1 \mathrm{~cm}$ in diameter (Fig. $6 \mathrm{j}$ ), begins north of the crater group and ends at the vent site \#8. On the plateau, the seafloor shows surficial white staining with ripple textures created by bottom currents and occasional native sulfur crusts. Area-wide diffuse shimmering water seepage was also identified. The crater group is located the southern end of South Peak crest (Fig. 5 a, red dotted circle). This group features several small (max. $10 \mathrm{~m}$ diameter) and shallow $(<3 \mathrm{~m})$ craters (Fig. $6 \mathrm{i})$. The seafloor around the craters is littered with unsorted clasts of variable sizes. The dominant clast size is $<10 \mathrm{~cm}$, but outsized blocks in the range of 10 's of $\mathrm{cm}$ were also observed. Diffuse venting of clear fluids was noticeable, with native sulfur crusts at some crater rims. No fluidal clasts or pyroclastic deposits were observed. 
In the southwestern corner of the overall edifice (Figure 5a) is a NE-striking knife-like ridge that was visited in 2011. An ROV Quest dive observed outcrops of coherent volcanic rock on the ridge. The ROV-based bathymetry was identical to the AUV bathymetry from 2006, suggesting that the emplacement of the lava forming this ridge took place before 2006 and that it was not affected by the cryptodome emplacement at South Peak. The area north of the ridge, however, was filled with material from the 2006-2011 South Peak cryptodome eruption.

\subsection{Estimating the size of the South Peak eruption}

We compared ship-based bathymetry datasets from two RV Sonne cruises in 2002 (SO166) and 2011 (SO216) to track the volcanic evolution of North Su and to support our ROV observations. By using the same sonar system on the same ship (and leaving out the 2006 Revelle survey due to low data coverage) we seek to minimize any possible differences in the imaging sonar systems and resolution that could result in artifacts. We note here that the 2002 RV Sonne bathymetry correlates well with the observed bathymetry in 2006. We used the depth differences between the two RV Sonne datasets to measure the volume of erupted material (Figure 10). If we use $+/-10$ m cut-off (Fig. 10 a), the total area of positive changes is $7.2 \times 10^{5} \mathrm{~m}^{2}$ with a total volume of $12.6 \times 10^{6} \mathrm{~m}^{3}$. However, this cut-off yields small negative changes on the northern slope of $6 \times 10^{3} \mathrm{~m}^{2}$ with a volume of $-7.2 \times 10^{4} \mathrm{~m}^{3}$. We interpret these areas of volume loss to result from precision system uncertainties that likely includes: the grid interpolation process, the accuracy of navigation, and roll and pitch corrections. These uncertainties and the patchy distribution of values with $a+/-10 \mathrm{~m}$ cut-off suggest that only changes $>+/-20 \mathrm{~m}$ represent robust results. 
Using this conservative $+/-20 \mathrm{~m}$ cut-off results in a calculated volume of $5.8 \times 10^{6} \mathrm{~m}^{3}$ that covers an area of $2.1 \times 10^{5} \mathrm{~m}^{2}$ and no negative values. The maximum depth change due to the eruption is $+63 \mathrm{~m}$ (Fig. 10). Our analyses suggest that the total erupted volume of South Peak is approximately $6 \times 10^{6} \mathrm{~m}^{3}$. For comparison, following the Plinian eruption of Mt. St. Helens in 1980, an episode of dome-growth between 1980 - 1986 produced 74 $x 10^{6} \mathrm{~m}^{3}$ of lava (Swanson and Holcomb, 1990) and the $2004-2008$ dome-volume totaled $93 \times 10^{6} \mathrm{~m}^{3}$ (Major et al., 2009). The total volume of North Su volcano is $265 \mathrm{x}$ $10^{6} \mathrm{~m}^{3}$, assuming the geometry of an ideal cone with a radius of $750 \mathrm{~m}$ at its base and a height of $450 \mathrm{~m}$. It would require on the order of 44 South Peak eruptions to build up North Su volcano.

\subsection{Rock samples}

\subsubsection{Unaltered Lava}

Whole rock analyses by XRF (appendix, Table A1; sample positions in Fig. 5) from North Su samples from 2006 reveal that unaltered rocks plot inside the andesite field inside the TAS diagram (Appendix Fig. 1; TAS = Total Alkali vs. Silica, Le Bas et al., 1986) with $\mathrm{SiO}_{2}$ contents in the range from 60 to $62.5 \mathrm{wt}$.\% $\mathrm{SiO}_{2}$. The $\mathrm{SiO}_{2}$ content of glass varies between 68 - 73 wt.\% $\mathrm{SiO}_{2}$ for samples from 2006 (e.g. Beier et al., 2015). The texture is porphyritic with moderate vesicularity and phenocrysts of clinopyroxene, orthopyroxene, Ca-rich plagioclase, olivine and Fe-Ti oxides in a dacitic to rhyolitic matrix. Electron microprobe analyses of unaltered rock samples from the new South Peak cryptodome eruption (2006 - 2011) and from previous eruptions (pre 2006) showed the same crystal content, composition and rock texture. Glass measurements 
were difficult to establish due to the vast abundance of plagioclase microliths within all samples (Fig. 8 i).

\subsubsection{Volcaniclastic deposit}

Sample SO-216-51-ROV-10 (Fig. 6 j) originates from the recently erupted South Peak cryptodome summit and contains a wide range of different clasts that have a relatively angular to rounded shape (Fig. 8 e). The clasts range from non-altered glassy fragments and non-altered crystals to completely altered clasts with advanced argillic alteration and including minor hydrothermal precipitates (gypsum, pyrite, sulfur). The rare glassy clasts host abundant plagioclase microliths (Fig. 8 i). Free crystal fragments comprise clinoand orthopyroxene, plagioclase, olivine, and Fe-Ti oxides. Incorporated accessory lithic clasts (highly altered volcanic rocks of the same volcano) inside non-altered volcanic clasts are rare. Sieving and weighting revealed that 87 wt. \% of sample SO-216-51ROV-10 are clasts being $<4 \mathrm{~mm}$.

We refrain from applying statistical methods on the volcaniclastic deposit and transfer the findings onto the entire eruption as we have only one sample from the new cryptodome. Therefore we concentrate on qualitative information only.

It was impossible to distinguish juvenile from non-altered accessory lithic clasts of previous eruptions, similar to what Pardo et al. (2014) discussed. Non-altered volcanic clasts are porphyritic and blocky and showed the same shape under microscope as manually broken pieces of the same volcanic rock. Furthermore, we couldn't find any bubble wall fragments, pumices or fluidal shaped clasts that would indicate that liquid magma was explosively ejected into the ocean. Therefore, we distinguish between nonaltered and altered clasts only. Samples of volcaniclastic deposits from the older North 
Peak summit share the same characteristic (crystal fragments, dominant grain size $<4 \mathrm{~mm}$, variably altered volcanic clasts) with the deposit from the new South Peak cryptodome but are dominated by hydrothermal precipitates and completely altered clasts. We conclude that such volcaniclastic deposit is typical for volcanic eruptions at North Su and that the different proportions of altered and non-altered volcanic clasts are linked to the prolonged exposure to hydrothermal fluids for deposits on the older North Peak compared to the relatively fresh deposit on the South Peak cryptodome.

\subsubsection{Hydrothermal breccias}

The summits of North and South Peak consist mainly of loose volcanic pebbles and sand. The recently formed South Peak cryptodome does not have any steep scarps to reveal the internal structure of the deposits so we can only interpret South Peak's geology based on its surface structures. In contrast, the older North Peak exposes its interior in cliff faces and pillars where poorly sorted clastic units of clasts with a thickness up to $16 \mathrm{~m}$ are exposed. These exposures indicate that the volcaniclastic deposit at the summit region of North Su can be several meters thick and partly consolidated to form breccias. Breccias were sampled directly from cliff faces (Fig. 12 a) and picked up from scree at the cliff base. These breccias are poorly sorted, dominantly matrix supported, and show a range of angular to sub-rounded clasts that are moderately to highly altered. The clasts range from cobble to sand size and represent a mixture of fractured bulk rock and phenocryst fragments. Electron Microprobe and X-ray diffraction analyses reveal that the clasts are partly altered to cristobalite and pyrophyllite, with variable alunite. Hydrothermal precipitates comprise alunite and jarosite, as well as cristobalite, pyrite, sulfur, and anhydrite that fills void space in between clasts and form vein networks within 
the breccias. Raster electron microscopy and element mapping shows compositional variations between the clasts and matrix (Figure 12 c-e). The element map of Si (Fig. 12 d) clearly defines the volcanic clasts whereas the element map of S (Fig. 12 e) highlights the hydrothermal cement in the void space between clasts.

In general, we distinguish three different morphologies formed by hydrothermal activity that appears to have increased slope stability at North Su: 1) fine volcaniclastic deposits cemented by various hydrothermal precipitates (Fig. 7 e and f); 2) excavated round pillars with a larger variety of clasts and clast-sizes (Fig. $7 \mathrm{~h}$ ); 3 ) hydrothermal crusts that cover clastic material (Fig. $7 \mathrm{c}$ and d). The first type of morphology is exhibited by vertical cliffs of fine volcaniclastic deposits on North Peak. Breccia samples have been taken out of these cliff faces. Petrographic inspection of several breccia samples in thin section and raster electron microscopy, and electron microprobe analyses indicates that volcanic clasts are commonly cemented by hydrothermal precipitates (Fig. 12). The bonding between the clasts can be accomplished by coalescence of these coatings, interstitial growth of individual crystals large enough to connect clasts, or complete infill of void space by polycrystalline cements, which often includes pyrite (Yeats et al., 2014). The occurrence of native sulfur in some of these breccias suggests that liquid sulfur impregnated the unconsolidated rubble and led to cementation upon cooling and solidification. Thin sections of breccia samples show that the clasts and crystal fragments reflect a similar clast composition as observed in sample SO-216-51-ROV-10, which originates from the summit of South Peak. Clasts of such cemented breccia samples are variably altered, but alteration of the breccia is never pervasive. Moreover, clay minerals are minor phases and never form interconnected networks in the rock, which would lower its shear strength. Cristobalite is perhaps the most abundant 
secondary mineral, partially replacing clasts and filling cracks and void space. In summary, the non-pervasive nature of alteration, the scarcity of clay minerals, the abundance of cristobalite and the varied styles of cementation all contribute to increase the shear strength relative to the unconsolidated precursor material of the cemented breccias.

The second morphology formed by hydrothermal cementation is presented by a sphalerite-barite crust (Fig. 7 d). This crust occurs on North Peak northwest slope at vent site \#5 (Fig. 5). We hypothesize that this is a result of a prolonged discharge of hydrothermal fluid into the gravel covered slope and precipitation of hydrothermal phases. On South Peak, the formation of such crust was observed (Fig. 7 c) where hydrothermal precipitates start to bury volcanic gravel.

The third morphology indicating that hydrothermal activity has increased slope stability is observed on the ridgeline next to Sulfur Candle. There, rounded pillars up to several meters high and $>1 \mathrm{~m}$ in diameter (Fig. $7 \mathrm{~h}$ ) consist of blocky volcanic clasts within a fine matrix. Native sulfur was pervasive and solidified tongues of sulfur were present on the vertical pillar surfaces with thicker sulfur deposits on the top. Similar looking structures have been observed at Brothers Volcano (de Ronde et al., 2011).

\section{Discussion}

The first discovery of North Su by video sled surveys and dredges in 1996 (Binns et al., 1997; Yeats et al., 2014), led to the interpretation of a dacite dome with a volcanic spine at its summit and associated black smoker chimneys. The entire volcanic edifice was 
interpreted to be covered by a thick "tuffite apron" (Binns et al., 1997). We verify the existence of a volcanic spine, black smoker chimneys and the volcaniclastic deposit at North Peak. "Tuffite" is a genetic term that includes pyroclasts and submarine pyroclast formation is still a topic of some debate (e.g. White et al., 2003). Hence we describe this lithology simply as volcaniclastic deposit.

Presence of mafic phenocrysts (olivine) in North Su rock samples was also found by Yeats et al. (2014) and distinguishes these rocks from the nearby Suzette and South Su rocks. Yeats et al. (2014) classify the South and North Su samples as porphyritic dacites due to the amount of siliceous groundmass. Our whole rock analyses of unaltered volcanic rocks from the crest of North Su range from 60 to 62.5 wt. \% $\mathrm{SiO}_{2}$ whereas samples from Yeats et al. (2014) of fresh volcanic rocks from the crest of North Su range from 62.5 to 62.8 wt. \% $\mathrm{SiO}_{2}$. The North Su rocks are porphyritic andesites.

\subsection{Deep submarine eruption of porphyritic andesitic lava}

Emplacement of viscous lava in a submarine environment is typically envisioned as the extrusion of a thick lobe or dome that is fragmented through quenching, coolingcontraction granulation upon contact with seawater and autobrecciation. This results in a massive or banded columnar jointed core that is covered by a monomictic carapace of breccia from quench fracturing (hyaloclastites) and mechanical disintegration during outflow (autobreccia) (e.g. Pichler, 1965; Yamagishi and Dimroth, 1985; McPhie et al., 1993; Goto and McPhie, 1998; Scutter et al., 1998; Doyle and McPhie, 2000; De Rita et

al., 2001; Nemeth et al., 2008). For example, PACManus Hydrothermal Area, $50 \mathrm{~km}$ 
West of North Su, hosts several dacite domes showing these characteristics (Thal et al., 2014).

On North Su, we observed several eruption products and volcanic morphologies including different types of lavas such as short and thick flows, columnar joints, autobrecciated blocky flows and spines (Fig. 6 a - e). These lava morphologies indicate flow behavior consistent with high-viscosity lava. Craters, indicative of explosivity, are also present, as well as the presence of abundant volcaniclastic deposits, which suggests that North Su does not fit easily into common models of submarine volcanic lava dome/cryptodome eruptions

On South Peak, no hyaloclastites or monomictic autobreccia deposits have been identified. To understand the eruption products of North $\mathrm{Su}$, it is essential to consider eruption mechanisms that are related to porphyritic andesites.

A subaerial analog of a porphyritic andesite dome emplacement is the 1995 - 1999 eruption at Soufrière Hills Volcano, Montserrat (e.g. Robertson et al., 1998; Voight, 1999; Sparks et al., 2000; Clarke et al., 2002; Druitt and Kokelaar, 2002). This episode of volcanic activity exhibited dome growth and collapse accompanied by short-lived episodic sub-Plinian and Vulcanian explosions (Druitt et al., 2002; Sparks and Young, 2002), which are common on andesitic volcanoes (Morrissey and Mastin, 2000). The crystal-rich, andesitic magma contained $35-45$ vol.\% phenocrysts and dome growth was characterized by the extrusion of a hot crystalline solid that was unable to flow. Further injection of magma into the dome pushed out lava lobes and spines. Rheological stiffening of the lava also caused syn-eruptive cyclic plugging of the conduit, producing a 
pressure cap and leading to an over pressurized conduit that led to gas emissions, ashventing, dome collapse and explosions (Druitt et al., 2002). A dome collapse revealed that the interior of the dome was heavily fractured with single fractures up to $50 \mathrm{~m}$ long. Sparks (2000) suggests this brittle behavior indicates that the crystal-rich lava erupted in a solid state.

The observations from Soufrière Hills Volcano are only partly transferrable to North Su as the eruption style and previous degassing of the magma is strongly dependent on atmospheric pressures and air as the coolant. However, the lava morphologies and abundant clastic material produced during the eruption as well as the general physical properties of highly crystalline andesitic magma and its behavior observed at Soufrière Hills Volcano are useful analogs to North Su.

\subsubsection{Lava fragmentation, explosions and formation of the clastic facies at North}

\section{Su}

The volcaniclastic deposit on the new South Peak cryptodome summit is composed of fresh and variably altered volcanic clasts, crystal fragments and only minor glassy clasts and minor hydrothermal precipitates. These glassy clasts (Fig. 8 c) are not distinguishable through microscopy from clasts of the same volcanic rock that we produced through mechanical disintegration. We therefore interpret these glassy clasts to be pieces of spattered bulk rock produced after solidification of lava rather than disrupted liquid lava. This can be explained by the ability of crystal-rich magma to fail as a brittle solid, similar to observation made on Soufrière Hills Volcano (e.g. Sparks et al., 2000; Melnik and Sparks, 2002). Additionally, Yamagishi \& Dimroth (1985) assume that 
a silica-rich magma with porphyritic texture would create blocky, stubby flows or domes that grade into breccia composed predominantly of blocky material. The fact that nonaltered clasts are blocky and no fluidal clasts are observed within volcaniclastic deposits on the new South Peak cryptodome, but also in no other sample from North Peak, implies magma fragmentation in the brittle regime is common on North Su volcano. The high crystal content can be explained by a strongly degassing magma while uprising or by magma ponding prior to the eruption. Beier et al. (2015) deduce from their investigations that magma genesis in the SER happens through closed system fractionation in several small magma lenses coupled with low rates of basaltic recharge. This could explain the occurrence of olivines inside the more evolved North Su lavas and the high crystal content. Observed strong magmatic degassing in the aftermath of the South Peak cryptodome eruption indicated a former gas-rich magma. Degassing would cause a lowering of the liquidus and cause further crystallization and thus also favor a brittle failure of the lava up on mechanical stress.

Theories of clast formation and explosivity due to water-magma interaction include several thermo-hydraulic fracturing mechanisms that account for different clast sizes and shapes (e.g. Sheridan and Wohletz, 1983; Wohletz, 1983; Kokelaar, 1986; Zimanowski et al., 1991; White, 1996; Skilling et al., 2002; Head and Wilson, 2003; Thiéry and Mercury, 2009). For lava that fails by brittle behavior, blocky clasts are mainly produced through quenching (cooling-contraction granulation), mechanical stress (autobrecciation) and hydromagmatic explosions (bulk interaction steam explosivity) (Kokelaar, 1986; Skilling et al., 2002; Head and Wilson, 2003). 
This accounts for the abundance of blocky clasts and the thick volcaniclastic deposit on the new South Peak cryptodome but does not explain the crater group.

The crater group comprises multiple, small, shallow and intersecting craters within the volcaniclastic deposit at the new South Peak cryptodome summit. Bigger $(>10 \mathrm{~cm})$ blocks are limited to the closer area of the craters. A morphological analog from land for multiple, shallow and intersecting craters is described by Thorarinsson (1953) for the crater group on Iceland where lava emplacement onto a wet substrate caused rootless explosions that created abundant small craters. We dismiss this scenario as lava at North Su is not capable of forming widespread lava flows that could cover a reasonable area of wet sediment.

A perhaps more similar analog are hydrothermal eruptions (Browne and Lawless, 2001) that eject blocky to rounded lithic clasts from predominantly shallow and small craters. Browne and Lawless (2001) consider the injection of magma into a deep hydrothermal aquifer to cause a phreatomagmatic explosions without juvenile material reaching the surface besides a hydrothermal explosion caused by expansion of a low-density, phaseseparated, hydrothermal fluid or steam (Browne and Lawless, 2001). In the latter case, a crack taps into a subsurface reservoir of such a fluid and the related sudden pressure drop causes catastrophic volume expansion and leading to an explosion. This mechanism is unlikely to cause large explosions in the deep sea because the ambient seafloor pressure (i.e., 115 bar at North Su) would prevent much of the gas expansion. 
Phreatomagmatic vent-derived explosions are also unlikely to occur at North Su given the water depth of $>1000 \mathrm{~m}$ (Kokelaar, 1986; Head and Wilson, 2003). Therefore, it is most likely that bulk-interaction steam explosivity is the only type of hydrovolcanic explosion that occurs at North Su. We hypothesize that, intense fracturing, hydrovolcanic explosions and magmatic degassing cause gas-jets that form the crater group on South Peak.

We propose that South Peak and its observed morphology was formed by the following sequence of eruption mechanisms (illustrated in Figure 13), which form the primary eruptive style at North Su:

i) Highly viscous, crystal-rich intermediate magma intrudes slowly into the watersaturated slope of North Su and its hydrothermal system. The slope consists of coherent lava and abundant clastic material, which is variably altered. Additional altered and lithic material might be contributed by upward transportation of vent wall-rocks with the rising magma. The cryptodome fails with brittle behavior upon contact with cold seawater due to the induced dynamic stress and autobrecciation, cooling-contraction granulation and bulk-interaction steam explosivity. Each new crack in the cryptodome enlarges the contact surface to cold seawater what causes further cracking and thus creates a selfamplifying fragmentation process. Additional rising magma occasionally pushes a fraction of magma through the pile of syn-eruptive and pre-existing clasts onto the seafloor in the form of lobes (Figure 13). These lobes, depending on their rheology during emplacement, either form short and rugged flows or disintegrate upon contact with sea water and remain as ragged outcrops without surficial signs of lava flow. 
ii) In the course of the eruption, high pressures, caused by the degassing magma, can develop within the dome or inside the conduit that is plugged by the dome itself and cause gas-jets or relatively small explosions. We exclude a serious vent plugging and subsequent serious explosion in this cryptodome eruption due the absence of a major crater. The magmatic gas driven explosions as well as the bulk-interaction steam explosivity fracture the lava and the surrounding country rock. The gas released by these explosions and uprising gas-jets causes a turbulent mixing of blocky juvenile fragments (i.e., fragmented intruding magma) and variably altered lithologies. This mixture of clasts will also be uplifted in the course of further injection of magma. Mechanical as well as gas-propelled turbulent reworking cause clasts to develop variably rounded shapes.

iii) The numerous small intersecting craters are likely caused by gas-jets that transport clasts of variable origin, shape, and size to the seafloor where they form a lithology that mimics products of hydrothermal eruptions (Browne and Lawless, 2001). Strong currents transport parts of the ejected material a few meters towards North Peak where they deposit and build up the plateau of dominantly sand-sized clasts. Larger clasts remain closer to the crater center or tumble further down slope and cause a fining-upward cycle on the upper slopes of South Peak cryptodome.

These proximal volcanic lithology patterns share characteristics (i.e. rounded grains, fine clast size, variably altered clasts) of deposits that would traditionally be interpreted in facies reconstructions as distal or as reworked volcaniclastic deposits. Our results 
indicate that heterolithic breccias with variably rounded clasts may also form during the course of the complex porphyritic magma-water interactions associated with a cryptodome eruption at the summit of an andesitic volcano. Downey and Lentz (2006) corroborate this hypothesis by modeling deep submarine explosive eruptions and by stating that volcaniclastic sediments, which are common in both the hanging and footwall of VMS deposits (Gibson et al., 1999), can be genetically connected to the formation of the VMS deposit, although these volcanic sediments are often interpreted as mass waste deposits. Examples are the Bald Mountain Cu-Zn deposit (Busby et al., 2003; Foley, 2003) and the Brunswick No. 6 and No. 12 Pb-Zn deposits (Downey and Lentz, 2006).

\subsection{Evidence of violent explosive eruptions}

In 2006, South Peak crater, $80 \mathrm{~m}$ wide and $13 \mathrm{~m}$ deep, was observed (Fig. $5 \mathrm{a}, 11$ ) on the southern flank of North Su - this crater was filled by the South Peak cryptodome eruption. The crater shape resembled the typical type of tuff ring or tuff cone that is associated with phreatomagmatic eruptions. Given the hydrostatic pressure of 115 bar at North Su summit, a phreatomagmatic explosion is highly unlikely to have caused the formation of this crater.

Based on dredge samples and photo-sled surveys during PACMANUS-III expedition in 1996, Binns (2004), Hrischeva et al. (2007) and Yeats et al. (2014) suggested that violent hydrothermal eruptions at North $\mathrm{Su}$ and South Su generate the abundance of volcaniclastic deposits and that such eruptions disperse these deposits for several $\mathrm{km}$. The terminology "hydrothermal eruption" describes a type of eruption that is defined as not involving magma but is fueled only by steam expansion due to a sudden pressure 
drop (Browne and Lawless, 2001). At North Su, a large extent of steam expansion due to a sudden pressure drop is unlikely given the hydrostatic pressure of $>115$ bar and any additional but unknown lithostatic pressure at the hydrothermal aquifer. Although it is not impossible to create a gas phase in an aquifer at a high pressure regime (e.g. Thiéry and Mercury, 2009; Buttinelli et al., 2011), this mechanism requires particular circumstances (i.e. assimilation of carbonates) and has never been described or observed in a deep sea environment.

In 2011, magmatic degassing was vigorous at North Su, which is common for evolved volatile-rich, arc-related magma systems (e.g. Carey and Sigurdsson, 2007). Following the discussion about a plugged conduit and regarding the fact that Vulcanian explosions are common on subaerial andesite volcanoes (Morrissey and Mastin, 2000), many effusive eruptions follow an explosive vent clearing phase. We hypothesize that the South Peak crater is a remnant of the vent clearing phase to the effusive eruption episode that produced South Peak cryptodome and discard the violent hydrothermal eruption theory.

Based on our analyses and observations we hypothesize that the South Peak cryptodome eruption is common for eruptions at the North Su volcano. Following this idea, North Peak presents the seafloor structures that will be present on South Peak after several years of hydrothermal activity and mass wasting events.

\subsection{Hydrothermally increased slope stability}


The upper slopes (shallower than $\sim 1350$ m water depth) of North Peak show a highly irregular topography, with steep pillars and cliffs that are exclusively composed of breccias. These observations suggest a vital role for cementation because any unconsolidated pile of volcanic clasts would have low cohesive strength and could not build steep walls and pillars.

Hydrothermal alteration processes are often considered a mechanism that decreases slope stability (e.g. Merle and Lénat, 2003), because clay minerals and other alteration phases commonly have lower shear strength than the primary phases they replace. However, our observations of volcaniclastic cliffs, pillars and hydrothermal crusts point to hydrothermal processes that lead to a precipitation of a cementing matrix that can lead to stabilization of a weak substrate such as volcaniclastic deposits.

We conclude that these pillars at North Su represent former localized fluid upflow-zones. Sulfur-laden fluids circulated through the volcaniclastic deposits prior to a sector collapse and solidified in between the clasts. This process is indicated at hydrothermal vent sites on South Peak where hydrothermal fluids start to bury loose rocks due to precipitation of native sulfur. Additionally, when we retracted the Temperature-probe after sticking it into the gravel next to a vent site, it was covered with native sulfur, indicating that the gravel-covered slope around the vents is saturated with liquid sulfur. Furthermore, we observed that the discharge of liquid sulfur is highly episodic (Fig. 9), which could account for the non-pervasive alteration of volcanic clasts inside these pillars as the fluid circulation is not necessarily continuous. We hypothesize this to be a 
cyclic pattern that accompanies volcanic eruptions on North Su as abundant volcaniclastic deposits are produced during lava emplacement, followed by hydrothermal discharge through the volcaniclastic pile leading to localized cemented structures that protrude from the slope after sector collapse events have led to the removal of less stable portions of the slope.

\section{Summary and Conclusion}

Our analyses show that North Su is now a double-peaked (North Peak and South Peak) active andesite volcano with a vigorous and varied hydrothermal system. Black and white smoker fluids discharge less than $100 \mathrm{~m}$ lateral distance from each other indicating a complex subsurface interconnected hydrothermal plumbing system. $\mathrm{CO}_{2}$ release is ubiquitous at "pulsating" white smoker vents and these vents apparently vary significantly in activity over a two-week observation period. A new vent site "Sulfur Candle" consisting of chimneys of native sulfur was documented following the 2011 observations. The pervasive volcaniclastic cover on North Su is partly cemented by hydrothermal processes and strongly influences the seafloor morphology of North Su North Peak. Hydrothermally-cemented breccias, crusts and single pillars show that hydrothermal circulation through a thick layer of volcaniclastic deposits can temporarily increase slope stability through precipitation and cementation.

Repeated bathymetric surveys reveal that South Peak cryptodome was emplaced between 2006 and 2011 on the southwestern slope of North Su volcano. Volcanic material with an estimated volume of $5.8 \times 10^{6} \mathrm{~m}^{3}$ was deposited over an area of $2.1 \mathrm{x}$ $10^{5} \mathrm{~m}^{2}$ with a maximum depth change between the surveys of $+63 \mathrm{~m}$. Comprehensive 
pre- and post-eruption mapping allow us to develop an eruption scenario where highly viscous, crystal-rich intermediate magma intrudes into the water-saturated, graveldominated slope of North Su and its hydrothermal system. Intense, fragmentation of the magma upon contact with cold seawater produces abundant blocky juvenile clasts. At North Su the abundance of blocky clasts and the lack of fluidal clasts indicative for quenched liquid lava is interpreted as a result of a cooled, high-viscosity, crystal-rich magma that fails as a brittle solid upon stress. The high viscosity allowed the lava to form dominantly blocky and short lava lobes. Magmatic degassing and bulk-interaction steam explosivity cause relatively small explosions which further fracture the lava and the surrounding country rock. These explosions and the consequently released gas as well as the updoming during further injection of magma cause a mixing of juvenile and pre-existing lithic clasts and variably rounded shapes. Gas jets produced by the explosions transport such mixed volcaniclastic deposit to the seafloor where they form numerous small intersecting craters, mimicking the lithology and morphology of hydrothermal eruptions.

Our observations provide further insight into the volcanologic framework of a developing Cu-Au ore deposit (Yeats et al., 2014) and can help geologists with facies interpretation. Proximal volcanic lithologies on North Su share characteristics (i.e. rounded grains, fine clast size, varied composition) with deposits that would traditionally be interpreted in facies reconstructions as distal or as redeposited lithologies. Our results indicate that such mixed volcaniclastic deposit with variably rounded clasts may also form in the course of the complex porphyritic magma-water interactions associated with a lava cryptodome eruption at the summit of an andesitic volcano. 


\section{Acknowledgments}

We thank Sharon Allen and Karoly Nemeth for very thoughtful and productive reviews. We thank the captains and crews of RV Sonne and RV Melville, the ROV teams of Jason-2 and MARUM Quest 4000, the AUV-ABE technical team and the members of the Science Parties for both cruises. Many thanks go to Dominik Niedermeyer for contributing geochemical analyses and to Timothy Schroeder for helpful discussions about the manuscript. We thank Adam Soule and Daniel Fornari for fruitful discussions on submarine volcanism and for the assistance in classifying the volcaniclastic deposit. Crucial help with bathymetry data processing was provided by Christian dos Santos Ferreira and Paul Wintersteller. The RV Melville work was funded by a combination of the US National Science Foundation grant OCE-0327448 and a collaborative research funding grant from Nautilus Minerals for the ABE surveys. The RV Sonne research cruise was funded through the BMBF (Grant G03216a). Additional funding, including salary support for JT, was provided by the German DFG Research Centre/Excellence Cluster "The Ocean in the Earth System". WB acknowledges support from DFG research grant BA1605/4-1. Finally, we thank Jim Robins and Pat Pepena from Papua New Guinea (PNG) for their help with PNG research permitting. 


\section{References}

Allen, S.R., Fiske, R.S., Tamura, Y., 2010. Effects of water depth on pumice formation in submarine domes at Sumisu, Izu-Bonin arc, western Pacific. Geology 38, 391-394.

Allen, S.R., McPhie, J., 2009. Products of neptunian eruptions. Geology 37, 639-642.

Auzende, J.-M., Ishibashi, J.-I., Beaudoin, Y.C., Charlou, J.-L., Delteil, J., Donval, J.-P., Fouquet, Y., Ildefonse, B., Kimura, H., Nishio, Y., Radford-Knoery, J., Ruøllan, E., 2000. Extensive magmatic and hydrothermal activity documented in Manus Basin. Eos, Transactions American Geophysical Union 81, 449-453.

Auzende, J.-M., Urabe, T., Party, S., 1996. Cruise explores hydrothermal vents of the Manus Basin. Eos (Transactions, American Geophysical Union) 77, 244.

Bach, W., Jöns, N., Thal, J., Breuer, C., Shu, L., Dubilier, N., Borowski, C., Meyerdierks, A., Pjevac, P., Brunner, B., Müller, I., Petersen, S., Hourdez, S., Schaen, A., Koloa, K., Jonda, L., Team, M.Q. 4000m, 2011. Report and preliminary results of RV SONNE Cruise SO-216, Townsville (Australia) - Makassar (Indonesia), June 14 July 23, 2011. BAMBUS, Back-Arc Manus Basin Underwater Solfataras. Berichte, Fachbereich Geowissenschaften, Universität Bremen 280, 87.

Beier, C., Bach, W., Turner, S., Niedermeier, D., Woodhead, J., Erzinger, J., Krumm, S., 2015. Origin of Silicic Magmas at Spreading Centres--an Example from the South East Rift, Manus Basin. Journal of Petrology 56, 255-272.

Binns, R.A., 2004. Eastern Manus basin, Papua New Guinea: Guides for volcanogenic massive sulphide exploration from a modern seafloor analogue, in: McConachy, T., Mclnnes, B. (Eds.), Copper-Zinc Massive Sulphide Deposits in Western Australia. CSIRO Explores, pp. 59-80.

Binns, R.A., Parr, J.M., 1993. Report on the Pacmanus II cruise-RV Franklin, Eastern Manus Basin, Papua New Guinea.

Binns, R.A., Scott, S., 1993. Actively forming polymetallic sulfide deposits associated with felsic volcanic rocks in the eastern Manus back-arc basin, Papua New Guinea. Economic Geology 88, 2226-2236.

Binns, R.A., Scott, S.D., Gemmell, J.B., Crook, K.A.W., Party, S., 1997. The SuSu Knolls Hydrothermal Field, Eastern Manus Basin, Papua New Guinea. Eos Transactions AGU Fall Meeting Supplement 78, \#V22E-02 (abstr.).

Browne, P., Lawless, J., 2001. Characteristics of hydrothermal eruptions, with examples from New Zealand and elsewhere. Earth-Science Reviews 52, 299-331.

Busby, C., Kessel, L., Schulz, K.J., Foose, M.P., Slack, J.F., 2003. Volcanic setting of the Ordovician Bald Mountain massive sulfide deposits, northern Maine, in: Goodfellow, W.D., McCutcheon, S.R., Peter, J.M. (Eds.), Massive Sulphide Deposits of the Bathurst Mining Camp, New Brunswick, and Northern Maine: Economic Geology Monograph 11. pp. 210-244.

Buttinelli, M., De Rita, D., Cremisini, C., Cimarelli, C., 2011. Deep explosive focal depths during maar forming magmatic-hydrothermal eruption: Baccano Crater, Central 
Italy. Bulletin of Volcanology 73, 899-915.

Carey, S., Sigurdsson, H., 2007. Exploring Submarine Arc Volcanoes. Oceanography 20, 80-89.

Chadwick Jr., W.W., Wright, I.C., Schwarz-Schampera, U., Hyvernaud, O., Reymond, D., de Ronde, C.E.J., 2008. Cyclic eruptions and sector collapses at Monowai submarine volcano, Kermadec arc: 1998-2007. Geochemistry, Geophysics, Geosystems 9, 1-17.

Clague, D.A., Paduan, J.B., Caress, D.W., Thomas, H., Chadwick Jr., W.W., Merle, S.G., 2011. Volcanic morphology of West Mata Volcano, NE Lau Basin, based on high-resolution bathymetry and depth changes. Geochemistry, Geophysics, Geosystems 12, 1-21.

Clarke, a B., Voight, B., Neri, A., Macedonio, G., 2002. Transient dynamics of vulcanian explosions and column collapse. Nature 415, 897-901.

Coleman, P.J., Packham, G.H., 1976. The Melanesian Borderlands and India - Pacific plates' boundary. Earth-Science Reviews 12, 197-233.

Crowhurst, P., Lowe, J., 2011. Exploration and resource drilling of seafloor massive sulfide (SMS) deposits in the Bismarck Sea, Papua New Guinea. OCEANS 2011 16.

De Rita, D., Giordano, G., Cecili, A., 2001. A model for submarine rhyolite dome growth: Ponza Island (central Italy). Journal of Volcanology and Geothermal Research 107, 221-239.

de Ronde, C.E.J., Hannington, M.D., Stoffers, P., Wright, I.C., Ditchburn, R.G., Reyes, A.G., Baker, E.T., Massoth, G.J., Lupton, J.E., Walker, S.L., Greene, R.R., Soong, C.W.R., Ishibashi, J., Lebon, G.T., Bray, C.J., Resing, J.A., 2006. Evolution of a Submarine Magmatic-Hydrothermal System: Brothers Volcano, Southern Kermadec Arc, New Zealand. Economic Geology 100, 1097-1133.

de Ronde, C.E.J., Massoth, G.J., Baker, E.T., Lupton, J.E., 2003. Submarine hydrothermal venting related to volcanic arcs, Giggenbach Memorial Volume, in: Simmons, S.F., Graham, I.J. (Eds.), Volcanic, Geothermal and Ore-Forming Fluids: Rulers and Witnesses of Processes within the Earth. Society of Economic Geologists, pp. 91-110.

de Ronde, C.E.J., Massoth, G.J., Butterfield, D. a., Christenson, B.W., Ishibashi, J., Ditchburn, R.G., Hannington, M.D., Brathwaite, R.L., Lupton, J.E., Kamenetsky, V.S., Graham, I.J., Zellmer, G.F., Dziak, R.P., Embley, R.W., Dekov, V.M., Munnik, F., Lahr, J., Evans, L.J., Takai, K., 2011. Submarine hydrothermal activity and goldrich mineralization at Brothers Volcano, Kermadec Arc, New Zealand. Mineralium Deposita 46, 541-584.

Deardorff, N.D., Cashman, K. V., Chadwick Jr., W.W., 2011. Observations of eruptive plume dynamics and pyroclastic deposits from submarine explosive eruptions at NW Rota-1, Mariana arc. Journal of Volcanology and Geothermal Research 202, 47-59. 
Downey, W.S., Lentz, D.R., 2006. Igneous rock associations 6. Modelling of deep submarine pyroclastic volcanism: A review and new results. Geoscience Canada 33, 5-19.

Doyle, M.G., McPhie, J., 2000. Facies architecture of a silicic intrusion-dominated volcanic centre at Highway-Reward, Queensland, Australia. Journal of Volcanology and Geothermal Research 99, 79-96.

Druitt, T.H., Kokelaar, B.P., 2002. The Eruption of Soufrière Hills Volcano, Montserrat, from 1995-1999, Geological Society, London, Memoirs.

Druitt, T.H., Young, S.R., Baptie, B., Bonadonna, C., Calder, E.S., Clarke, a. B., Cole, P.D., Harford, C.L., Herd, R. a., Luckett, R., Ryan, G., Voight, B., 2002. Episodes of cyclic Vulcanian explosive activity with fountain collapse at Soufriere Hills Volcano, Montserrat. Geological Society, London, Memoirs 21, 281-306.

Embley, R.W., Chadwick Jr., W.W., Baker, E.T., Butterfield, D.A., Resing, J.A., de Ronde, C.E.J., Tunnicliffe, V., Lupton, J.E., Juniper, S.K., Rubin, K.H., Stern, R.J., Lebon, G.T., Nakamura, K., Merle, S.G., Hein, J.R., Wiens, D.A., Tamura, Y., 2006. Long-term eruptive activity at a submarine arc volcano. Nature 441, 494-7.

Falvey, D.A., Pritchard, T., 1982. Preliminary Paleomagnetic Results from Northern Papua New Guinea: Evidence for Large Microplate Rotations, in: Watson, S.T. (Ed.), Transactions of the Third Circum-Pacific Energy and Mineral Resources Conference. American Association of Petrolium Geologists, Tulsa, Oklahoma, pp. 593-600.

Foley, N.K., 2003. Thermal and chemical evolution of ore fluids and massive sulfide mineralization at Bald Mountain, Maine, in: Goodfellow, W.D., McCutcheon, S.R., Peter, J.M. (Eds.), Massive Sulphide Deposits of the Bathurst Mining Camp, New Brunswick, and Northern Maine: Economic Geology Monograph 11. pp. 549-566.

Gamo, T., Okamura, K., Charlou, J., Urabe, T., Auzende, J., Ishibashi, J., Shitashima, K., Chiba, H., Shipboard Scientific Party of the ManusFlux Cruise, 1997. Acidic and sulfate-rich hydrothermal fluids from the Manus back-arc basin, Papua New Guinea. Geology 25, 139-142.

Gibson, H.L., Morton, R.L., Hudak, G.J., 1999. Submarine volcanic processes, deposits, and environments favourable for the location of volcanic-associated massive sulfide deposits, in: Barrie, C.T., Hannington, M.D. (Eds.), Volcanic-Associated Massive Sulfide Deposits: Processes and Examples in Modern and Ancient Settings. Reviews in Economic Geology, pp. 13-51.

Golder Associates Pty Ltd, 2012. Mineral Resource Estimate, Solwara Project, Bismarck Sea, PNG.

Goto, Y., McPhie, J., 1998. Endogenous growth of a Miocene submarine dacite cryptodome, Rebun Island, Hokkaido, Japan. Journal of Volcanology and Geothermal Research 84, 273-286.

Hannington, M.D., de Ronde, C.E.J., Petersen, S., 2005. Sea-Floor Tectonics and Submarine Hydrothermal Systems. Economic Geology 100th Anniversary Volume 111-141. 
Hannington, M.D., Jamieson, J., Monecke, T., Petersen, S., Beaulieu, S., 2011. The abundance of seafloor massive sulfide deposits. Geology 39, 1155-1158.

Hashimoto, J., Ohta, S., Fiala-Médioni, A., Auzende, J., 1999. Hydrothermal vent communities in the Manus Basin, Papua New Guinea: Results of the BIOACCESS cruises' 96 and'98. InterRidge News 8 (2), 12-18.

Head, J.W., Wilson, L., 2003. Deep submarine pyroclastic eruptions: theory and predicted landforms and deposits. Journal of Volcanology and Geothermal Research 121, 155-193.

Hedenquist, J., Lowenstern, J., 1994. The role of magmas in the formation of hydrothermal ore deposits. Nature 370, 519-527.

Herzig, P.M., 1999. Economic potential of sea-floor massive sulphide deposits: ancient and modern. Philosophical Transactions of the Royal Society A: Mathematical, Physical and Engineering Sciences 357, 861-875.

Herzig, P.M., Kuhn, T., Petersen, S., Shipboard Scientific Party, 2002. Detailed investigation of the magmatic-hydrothermal gold mineralization at conical seamount (New Ireland Basin) and of massive sulfides at PACMANUS (Eastern Manus Basin), Papua New Guinea by shallow drilling : Cruise report - SO-166 CONDRILL. Freiberg.

Hillier, J.K., Watts, A.B., 2007. Global distribution of seamounts from ship-track bathymetry data. Geophysical Research Letters 34, L13304.

Hrischeva, E., Scott, S.D., Weston, R., 2007. Metalliferous sediments associated with presently forming volcanogenic massive sulfides: the SuSu Knolls hydrothermal field, eastern Manus Basin, Papua New. Economic Geology 102, 55-73.

lizasa, K., 1999. Potential Marine Mineral Resources by Hydrothermal Activity. Chemical Industry 50, 379-384.

Kokelaar, P., 1986. Magma-water interactions in subaqueous and emergent basaltic. Bulletin of Volcanology 48, 275-289.

Kroenke, L., Rodda, P., 1984. Cenozoic tectonic development of the Southwest Pacific. U.N. ESCAP, CCOP/SOPAC Tech. Bull. 6.

Le Bas, M.J., Le Maitre, R.W., Streckeisen, A., Zanettin, B., 1986. A Chemical Classificatron of Volcanic Rocks Based on the Total Alkali-Silica Diagram. Journal of Petrology 27, 745-750.

Leat, P.T., Tate, A.J., Tappin, D.R., Day, S.J., Owen, M.J., 2010. Growth and mass wasting of volcanic centers in the northern South Sandwich arc, South Atlantic, revealed by new multibeam mapping. Marine Geology 275, 110-126.

Major, J.J., Dzurisin, D., Schilling, S.P., Poland, M.P., 2009. Monitoring lava-dome growth during the 2004-2008 Mount St. Helens, Washington, eruption using oblique terrestrial photography. Earth and Planetary Science Letters 286, 243-254.

Martinez, F., Taylor, B., 1996. Backarc spreading, rifting, and microplate rotation, between transform faults in the Manus Basin. Marine Geophysical Research 18, 
203-224.

Martinez, F., Taylor, B., 2003. Controls on back-arc crustal accretion: insights from the Lau, Manus and Mariana basins. Geological Society, London, Special Publications 219, 19-54.

McPhie, J., Doyle, M.G., Allen, S.R., 1993. Volcanic textures: a guide to the interpretation of textures in volcanic rocks. Centre for Ore Deposit and Exploration Studies - University of Tasmania.

Melnik, O., Sparks, R.S.J., 2002. Dynamics of magma ascent and lava extrusion at Soufriere Hills Volcano, Montserrat. Geological Society, London, Memoirs 21, 153171.

Merle, O., Lénat, J.-F., 2003. Hybrid collapse mechanism at Piton de la Fournaise volcano, Reunion Island, Indian Ocean. Journal of Geophysical Research 108, 2166.

Morrissey, M.M., Mastin, L.G., 2000. Vulcanian eruptions, in: Sigurdsson, H., Houghton, B., Rymer, H. (Eds.), Encyclopedia of Volcanoes. Academic Press, San Diego, pp. 463-475.

Mosier, D.L., Berger, V.I., Singer, D.A., 2009. Volcanogenic massive sulfide deposits of the world; database and grade and tonnage models, U.S. Geological Survey OpenFile Report.

Moss, R., 2000. Geochemistry and mineralogy of gold in the PACMANUS and Susu knolls hydrothermal systems, eastern Manus basin, Papua New Guinea. University of Toronto.

Moss, R., Scott, S.D., 2001. Geochemistry and Mineralogy of Gold-Rich Hydrothermal Precipitates From the Eastern Manus Basin, Papua New Guinea. The Canadian Mineralogist 39, 957-978.

Nemeth, K., Pecskay, Z., Martin, U., Gmeling, K., Molnar, F., Cronin, S.J., 2008. Hyaloclastites, peperites and soft-sediment deformation textures of a shallow subaqueous Miocene rhyolitic dome-cryptodome complex, Palhaza, Hungary. Geological Society, London, Special Publications 302, 63-86.

Pardo, N., Cronin, S.J., Németh, K., Brenna, M., Schipper, C.I., Breard, E., White, J.D.L., Procter, J., Stewart, B., Agustín-Flores, J., Moebis, A., Zernack, A., Kereszturi, G., Lube, G., Auer, A., Neall, V., Wallace, C., 2014. Perils in distinguishing phreatic from phreatomagmatic ash; insights into the eruption mechanisms of the 6 August 2012 Mt. Tongariro eruption, New Zealand. Journal of Volcanology and Geothermal Research 286, 397-414.

Petersen, S., Herzig, P., Hannington, M.D., Gemmell, J.B., 2003. Gold-rich massive sulfides from the interior of the felsic-hosted PACMANUS massive sulfide deposit, Eastern Manus Basin (PNG), in: Eliopoulos et al. (Ed.), Mineral Exploration and Sustainable Development. Millpress, Rotterdam, pp. 171-174.

Pichler, H., 1965. Acid hyaloclastites. Bulletin Volcanologique 28, 293-310.

Resing, J.A., Rubin, K.H., Embley, R.W., Lupton, J.E., Baker, E.T., Dziak, R.P., 
Baumberger, T., Lilley, M.D., Huber, J.A., Shank, T.M., Butterfield, D.A., Clague, D.A., Keller, N.S., Merle, S.G., Buck, N.J., Michael, P.J., Soule, A., Caress, D.W., Walker, S.L., Davis, R., Cowen, J.P., Reysenbach, A.-L., Thomas, H., 2011. Active submarine eruption of boninite in the northeastern Lau Basin. Nature Geoscience 4, 799-806.

Robertson, R., Cole, P., Sparks, R.S.J., Harford, C., Lejeune, A.M., McGuire, W.J., Miller, A.D., Murphy, M.D., Norton, G., Stevens, N.F., Young, S.R., 1998. The explosive eruption of Soufriere Hills Volcano, Montserrat, West Indies, 17 September, 1996. Geophysical Research Letters 25, 3429-3432.

Sangster, D.F., 1980. Quantitative characteristics of volcanogenic massive sulphide deposits. Bulletin of the Canadian Institute of Mining and Metallurgy 73, 74-81.

Schipper, C.I., White, J.D.L., Houghton, B.F., Shimizu, N., Stewart, R.B., 2010. Explosive submarine eruptions driven by volatile-coupled degassing at Lō'ihi Seamount, Hawai i. Earth and Planetary Science Letters 295, 497-510.

Scutter, C., Cas, R.A.F., Moore, C., De Rita, D., 1998. Facies architecture and origin of a submarine rhyolitic lava flow-dome complex, Ponza, Italy. Journal of Geophysical ... 103, 27,551-27,566.

Sheridan, M.F., Wohletz, K.H., 1983. Hydrovolcanism: Basic considerations and review. Journal of Volcanology and Geothermal Research 17, 1-29.

Sinton, J.M., Ford, L.L., Chapell, B., McCulloch, M.T., 2003. Magma genesis and mantle heterogeneity in the Manus back-arc basin, Papua New Guinea. Journal of Petrology 44, 159-195.

Skilling, I.P., White, J.D.L., McPhie, J., 2002. Peperite: a review of magma-sediment mingling. Journal of Volcanology and Geothermal Research 114, 1-17.

Sparks, R.S.J., Murphy, M.D., Lejeune, A.M., Watts, R.B., Barclay, J., Young, S.R., 2000. Control on the emplacement of the andesite lava dome of the Soufriere Hills volcano, Montserrat by degassing-induced crystallization. Terra Nova 12, 14-20.

Sparks, R.S.J., Young, S.R., 2002. The eruption of Soufriere Hills Volcano, Montserrat (1995-1999): overview of scientific results, in: Druitt, T.H., Kokelaar, B.P. (Eds.), The Eruption of Soufrière Hills Volcano, Montserrat, from 1995 to 1999. The Geological Society of London, London, pp. 45-69.

Swanson, D.A., Holcomb, R.T., 1990. Regularities in Growth of the Mount St. Helens Dacite Dome, 1980-1986, in: Fink, J.H. (Ed.), Lava Flows and Domes. pp. 3-24.

Taylor, B., 1979. Bismarck Sea: Evolution of a back-arc basin. Geology 7, 171-174.

Taylor, B., Crook, K., Sinton, J., 1994. Extensional transform zones and oblique spreading centers. Journal of Geophysical Research 99, 19,707-19,718.

Thal, J., Tivey, M., Yoerger, D., Jöns, N., Bach, W., 2014. Geologic setting of PACManus hydrothermal area - High resolution mapping and in situ observations. Marine Geology 355, 98-114.

Thiéry, R., Mercury, L., 2009. Explosive properties of water in volcanic and hydrothermal 
systems. Journal of Geophysical Research 114, B05205.

Tivey, M.A., Bach, W., Seewald, J., Tivey, M.K., Vanko, D.A., Party, S.S., 2006. Cruise Report for R/V Melville Cruise MGLN06MV-Hydrothermal Systems in the Eastern Manus Basin: Fluid Chemistry and Magnetic Structure as Guides to Subseafloor Processes.

Tregoning, P., 2002. Plate kinematics in the western Pacific derived from geodetic observations. Journal of Geophysical Research 107, 1-8.

Tregoning, P., Jackson, R.J., Mcqueen, H., Larnbeck, K., Stevens, C., Little, R.P., Curley, R., Rosa, R., 1999. Motion of the South Bismarck Plate, Papua New Guinea. Geophysical Research Letters 26, 3517-3520.

Tregoning, P., Lambeck, K., Stolz, A., Morgan, P., McClusky, S.C., van der Beek, P., McQueen, H., Jackson, R.J., Little, R.P., Laing, A., Murphy, B., 1998. Estimation of current plate motions in Papua New Guinea from Global Positioning System observations. Journal of Geophysical Research 103, 12181.

Voight, B., 1999. Magma Flow Instability and Cyclic Activity at Soufriere Hills Volcano, Montserrat, British West Indies. Science 283, 1138-1142.

Watts, a. B., Peirce, C., Grevemeyer, I., Paulatto, M., Stratford, W., Bassett, D., Hunter, J. a., Kalnins, L.M., de Ronde, C.E.J., 2012. Rapid rates of growth and collapse of Monowai submarine volcano in the Kermadec Arc. Nature Geoscience 5, 510-515.

Wessel, P., 2001. Global distribution of seamounts inferred from gridded Geosat/ERS-1 altimetry. Journal of Geophysical Research 106, 19,431-19,441.

White, J.D.L., 1996. Impure coolants and interaction dynamics of phreatomagmatic eruptions. Journal of Volcanology and Geothermal Research 74, 155-170.

White, J.D.L., Smellie, J.L., Clague, D.A., 2003. Explosive subaqueous volcanism, Geophysica. ed. American Geophysical Union.

Wohletz, K.H., 1983. Mechanisms of hydrovolcanic pyroclast formation: Grain-size, scanning electron microscopy, and experimental studies. Journal of Volcanology and Geothermal Research 17, 31-63.

Wright, I.C., Gamble, J.A., Shane, P.A.R., 2003. Submarine silicic volcanism of the Healy caldera, southern Kermadec arc (SW Pacific): I-volcanology and eruption mechanisms. Bulletin of Volcanology 65, 15-29.

Yamagishi, H., Dimroth, E., 1985. A comparison of Miocene and Archean rhyolite hyaloclastites: evidence for a hot and fluid rhyolite lava. Journal of Volcanology and Geothermal Research 23, 337-355.

Yeats, C.J., Binns, R.A., Parr, J., 2008. The SuSu Knolls hydrothermal field, Eastern Manus Basin, Papua New Guinea: An actively forming submarine high sulfidation copper-gold system, in: International Geological Congress. Oslo, p. MRD-03.

Yeats, C.J., Parr, J.M., Binns, R.A., Gemmell, J.B., Scott, S.D., 2014. The SuSu Knolls Hydrothermal Field, Eastern Manus Basin, Papua New Guinea: An Active Submarine High-Sulfidation Copper-Gold System. Economic Geology 109, 2207- 
2226.

Zimanowski, B., Fröhlich, G., Lorenz, V., 1991. Quantitative experiments on phreatomagmatic explosions. Journal of Volcanology and Geothermal Research 48, 341-358. 


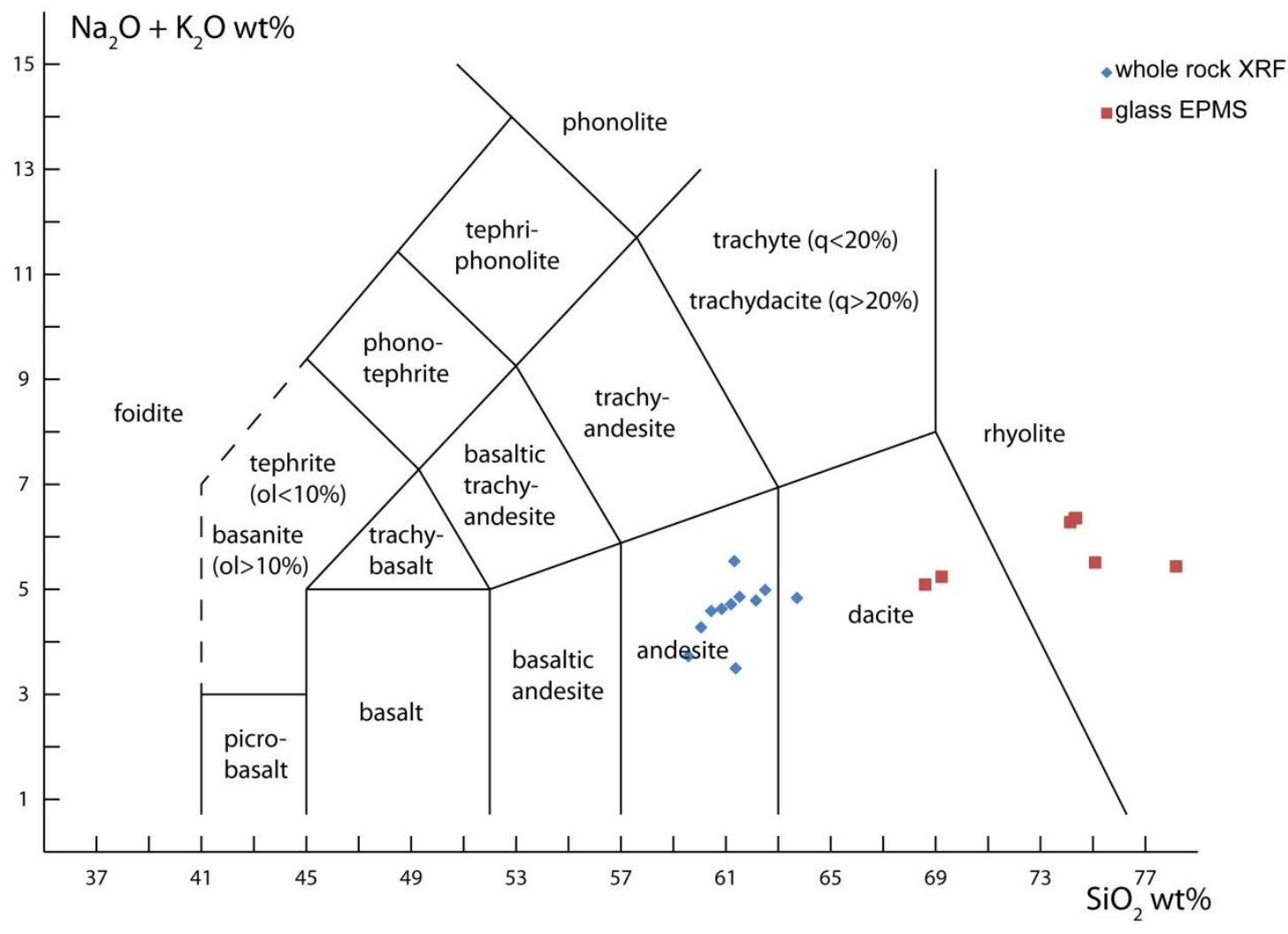

Fig. A1. TAS diagram of rock samples used in this study.

\begin{tabular}{|c|c|c|c|c|c|c|c|c|c|c|c|}
\hline \multirow[b]{3}{*}{ wt. } & \multicolumn{11}{|c|}{ Sample \# } \\
\hline & \multicolumn{4}{|c|}{ J2-221- } & \multicolumn{6}{|c|}{ J2-223- } & \multirow{2}{*}{$\begin{array}{r}\text { J2-227 } \\
\text { 13-R1 }\end{array}$} \\
\hline & 8-R1 & $\begin{array}{l}\text { 15- } \\
\text { R1 }\end{array}$ & $\begin{array}{l}\text { 16- } \\
\text { R1 }\end{array}$ & 16-R2 & 3-R1 & 5-R1 & 9-R2 & 10-R1 & $\begin{array}{l}\text { 14- } \\
\text { R1 }\end{array}$ & $\begin{array}{l}\text { 16- } \\
\text { R1 }\end{array}$ & \\
\hline $\mathrm{SiO} 2$ & 59.59 & 60.46 & 61.39 & 60.07 & 61.21 & 61.34 & 60.86 & 61.54 & 62.16 & 62.52 & 63.73 \\
\hline TiO2 & 0.54 & 0.56 & 0.56 & 0.55 & 0.57 & 0.57 & 0.56 & 0.58 & 0.58 & 0.57 & 0.56 \\
\hline $\mathrm{Al}_{2} \mathrm{O}_{3}$ & 13.95 & 14.69 & 14.69 & 14.36 & 14.90 & 14.69 & 14.83 & 14.78 & 14.97 & 14.85 & 14.76 \\
\hline $\mathrm{Fe}_{2} \mathrm{O}_{3}$ & 6.94 & 6.60 & 5.85 & 7.17 & 7.34 & 6.29 & 7.06 & 7.15 & 6.59 & 6.36 & 4.39 \\
\hline MnO & 0.130 & 0.127 & 0.120 & 0.138 & 0.152 & 0.120 & 0.131 & 0.132 & 0.128 & 0.122 & 0.086 \\
\hline $\mathrm{MgO}$ & 4.09 & 2.81 & 2.61 & 4.20 & 3.08 & 2.25 & 3.08 & 2.60 & 2.75 & 2.32 & 2.16 \\
\hline $\mathrm{CaO}$ & 6.48 & 5.96 & 5.81 & 7.05 & 6.44 & 5.78 & 6.43 & 5.90 & 6.12 & 5.50 & 5.21 \\
\hline $\mathrm{Na}_{2} \mathrm{O}$ & 2.94 & 3.60 & 2.69 & 3.40 & 3.73 & 4.41 & 3.65 & 3.82 & 3.77 & 3.90 & 3.95 \\
\hline $\mathrm{K}_{2} \mathrm{O}$ & 0.78 & 0.98 & 0.80 & 0.87 & 0.98 & 1.12 & 0.97 & 1.03 & 1.01 & 1.08 & 0.88 \\
\hline $\mathrm{P}_{2} \mathrm{O}_{5}$ & 0.17 & 0.15 & 0.13 & 0.17 & 0.21 & 0.19 & 0.19 & 0.20 & 0.19 & 0.19 & 0.09 \\
\hline $\mathrm{H}_{2} \mathrm{O}$ & 2.65 & 1.55 & 3.33 & 1.17 & 0.97 & 1.41 & 1.28 & 1.02 & 1.06 & 1.26 & 1.41 \\
\hline $\mathrm{CO}_{2}$ & 0.02 & 0.03 & 0.04 & 0.02 & 0.03 & 0.04 & 0.06 & 0.06 & 0.03 & 0.03 & 0.03 \\
\hline Total & 98.35 & 97.60 & 98.10 & 99.17 & 99.62 & 98.20 & 99.10 & 98.80 & 99.35 & 98.70 & 97.33 \\
\hline
\end{tabular}

Table A1: Results of whole rock XRF analyses. All iron measured as $\mathrm{Fe}_{2} \mathrm{O}_{3}$. 


\begin{tabular}{|c|c|c|c|c|c|c|}
\hline \multirow[b]{3}{*}{ wt. \% } & \multicolumn{6}{|c|}{ Sample \# } \\
\hline & \multicolumn{2}{|c|}{ J2-221- } & \multicolumn{4}{|c|}{ J2-223- } \\
\hline & 8-r1 & 16-r1 & 5-R1 & $9-r 2$ & 10-R1 & 14-r1 \\
\hline $\mathrm{SiO}_{2}$ & 66,87 & 68,18 & 74,11 & 72,90 & 74,45 & 73,51 \\
\hline $\mathrm{TiO}_{2}$ & 0,61 & 0,62 & 0,56 & 0,49 & 0,49 & 0,56 \\
\hline $\mathrm{Al}_{2} \mathrm{O}_{3}$ & 13,40 & 13,28 & 12,60 & 12,75 & 12,39 & 12,64 \\
\hline $\mathrm{Cr}_{2} \mathrm{O}_{3}$ & 0,000 & 0,000 & 0,010 & 0,000 & 0,017 & 0,017 \\
\hline $\mathrm{FeO}$ & 5,67 & 5,54 & 3,48 & 2,76 & 3,48 & 3,09 \\
\hline MnO & 0,12 & 0,13 & 0,09 & 0,10 & 0,08 & 0,06 \\
\hline MgO & 1,32 & 1,18 & 0,38 & 0,23 & 0,43 & 0,24 \\
\hline $\mathrm{CaO}$ & 3,99 & 3,85 & 2,06 & 2,13 & 2,02 & 2,04 \\
\hline $\mathrm{Na}_{2} \mathrm{O}$ & 3,53 & 3,65 & 4,35 & 3,64 & 4,41 & 4,43 \\
\hline $\mathrm{K}_{2} \mathrm{O}$ & 1,42 & 1,50 & 1,92 & 1,71 & 1,95 & 1,85 \\
\hline $\mathbf{P}_{2} \mathbf{O}_{5}$ & 0,29 & 0,30 & 0,13 & 0,10 & 0,21 & 0,12 \\
\hline $\mathrm{SO}_{3}$ & 0,02 & 0,01 & 0,00 & 0,00 & 0,00 & 0,00 \\
\hline $\mathrm{BaO}$ & 0,00 & 0,00 & 0,08 & 0,00 & 0,07 & 0,00 \\
\hline $\mathrm{Cl}$ & 0,22 & 0,22 & 0,26 & 0,26 & 0,26 & 0,27 \\
\hline Total & 97,46 & 98,46 & 99,93 & 97,06 & 100,17 & 98,82 \\
\hline
\end{tabular}

Table A2: Glass analyses measured with EPMA.

\begin{tabular}{|c|l|c|c|c|c|c|}
\hline Vent \# & \multicolumn{1}{|c|}{ Fluid type } & Year & Water depth [m] & Temperature $\left.{ }^{\circ} \mathbf{C}\right]$ & Lat & Lon \\
\hline $\mathbf{1}$ & Black Smoker & 2006 & 1158 & 298 & 152.1009 & -3.7999 \\
& & 2011 & 1154 & 314 & & \\
\hline $\mathbf{2}$ & Black Smoker & 2006 & 1157 & 300 & 152.1009 & -3.8002 \\
\hline $\mathbf{3}$ & Black Smoker & 2006 & 1194 & 324 & 152.1004 & -3.7999 \\
& & 2011 & 1192 & 332 & 152.1003 & -3.7998 \\
\hline $\mathbf{4}$ & Diffuse venting & 2006 & 1196 & 32 & 152.1014 & -3.7993 \\
& & 2011 & & 44 & & \\
\hline $\mathbf{5}$ & Hybrid vents & 2006 & 1207 & 240 & 152.1008 & -3.7991 \\
& & 2011 & 1228 & 169 & 152.1005 & -3.799 \\
\hline $\mathbf{6}$ & White Smoker & 2006 & 1263 & 284 & 152.1005 & -3.8012 \\
\hline $\mathbf{7}$ & White Smoker & 2006 & 1217 & 71 & 152.1015 & -3.8006 \\
& & 2011 & 1220 & 104 & 152.1015 & -3.8006 \\
\hline $\mathbf{8}$ & White Smoker & 2011 & 1202 & 79 & 152.1005 & -3.8006 \\
\hline
\end{tabular}

Table A3: List of hydrothermal vents at North Su with positions of temperature measurements, year and water depth. 


\section{All figures with captions}

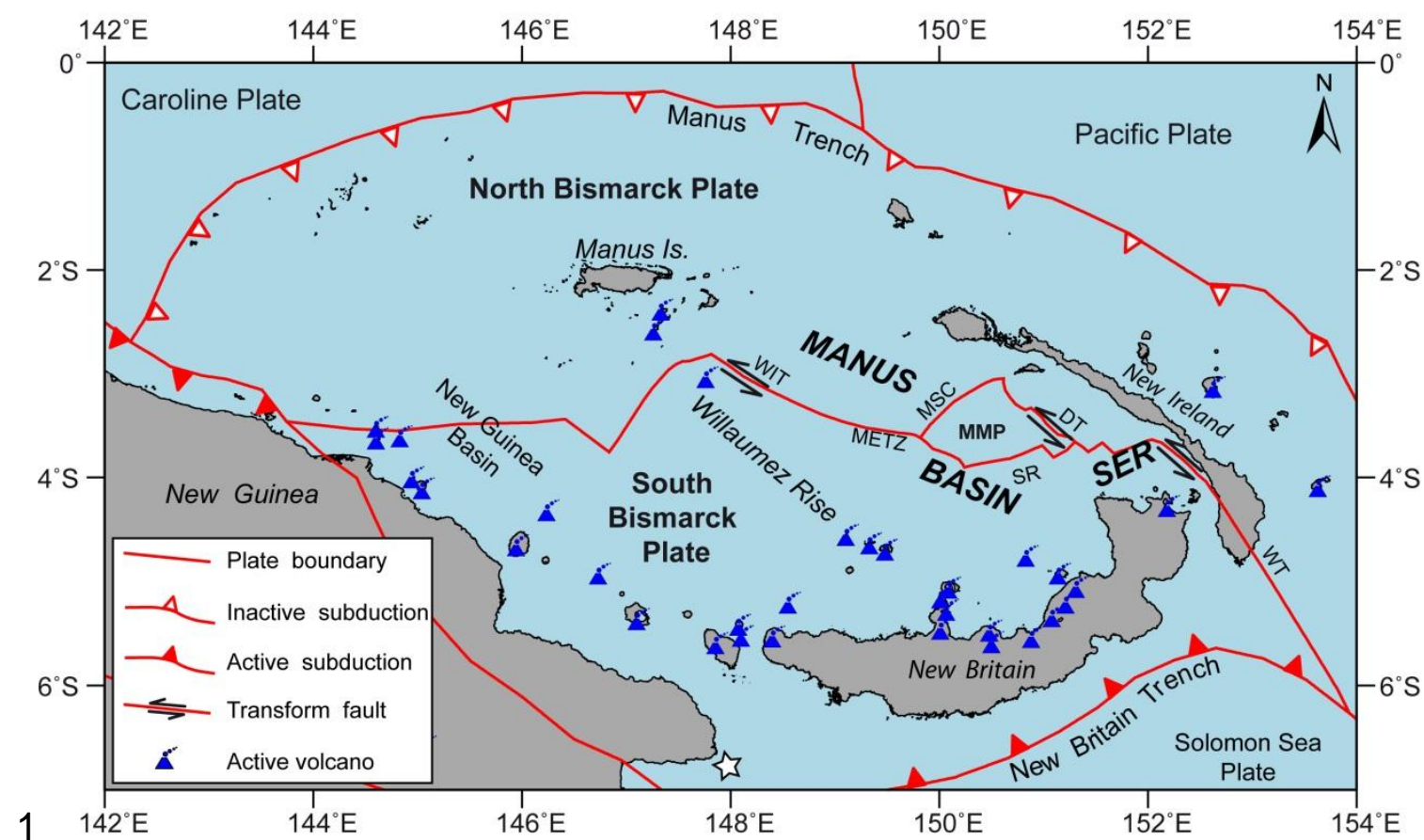

Fig. 1: Tectonic setting of the Bismarck Sea. Plate boundaries from (Bird, 2003). WIT: Willaumez Transform; MSC: Manus Spreading Center; MMP: Manus Microplate; DT: Djaul Transform; WT: Weitin Transform. (Thal et al., 2014)

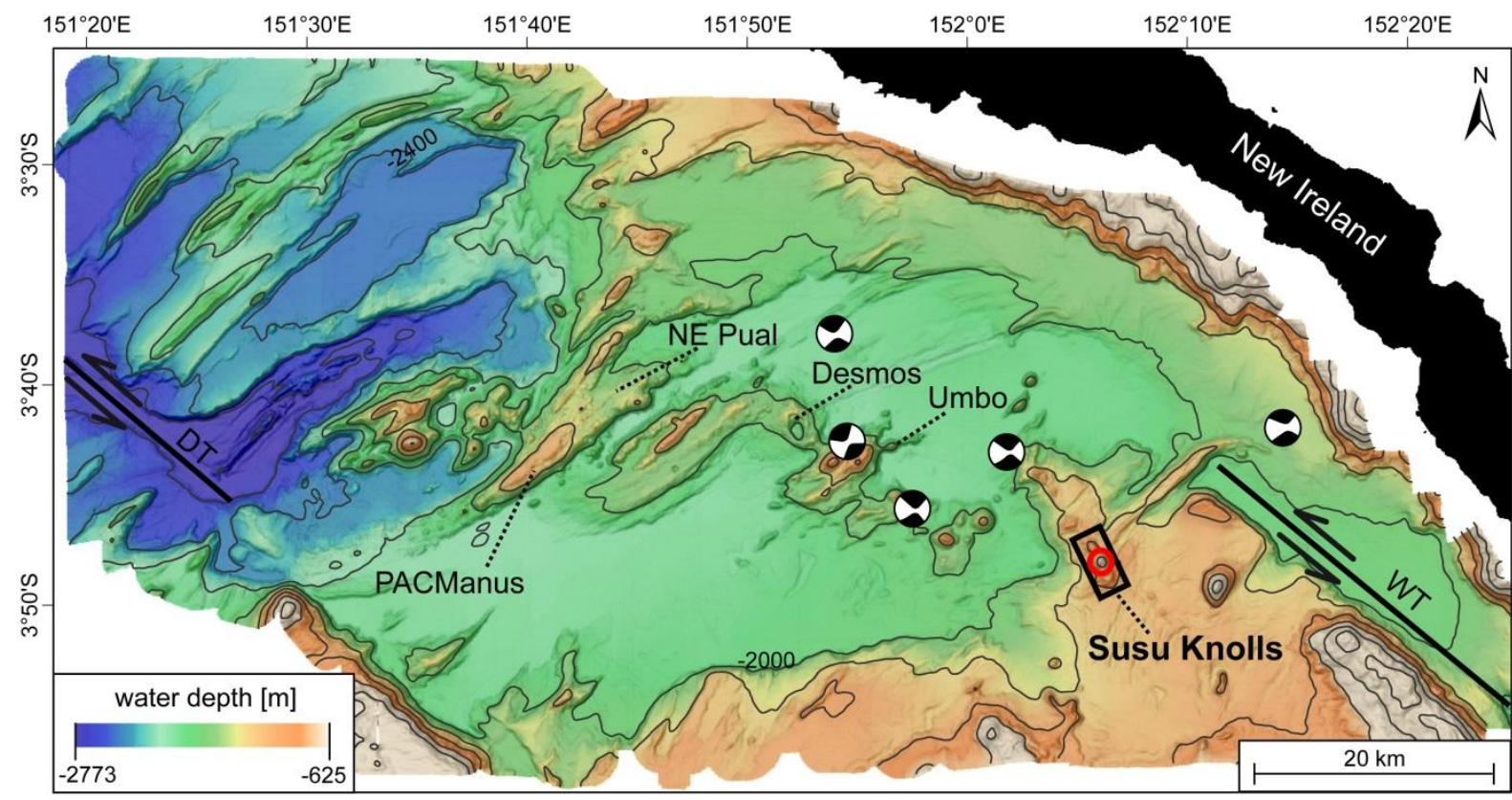

Fig.2: Bathymetry of the South East Ridges (SER) in the eastern Manus Basin from research cruise BAMBUS SO-216 (2011) with $200 \mathrm{~m}$ contours. Beachballs originate from the global $\mathrm{cmt}$ project (Dziewonski et al., 1981; Ekström et al., 2012) and mark the locations of earthquakes between 2006 \& 2011 with a magnitude $>5$. The movement depicted by beachballs represents the stepwise intratransform, extensional stress regime. DT: Djaul Transform; WT: Weitin Transform. Red circle: North Su. (Modified after Thal et al., 2014). 


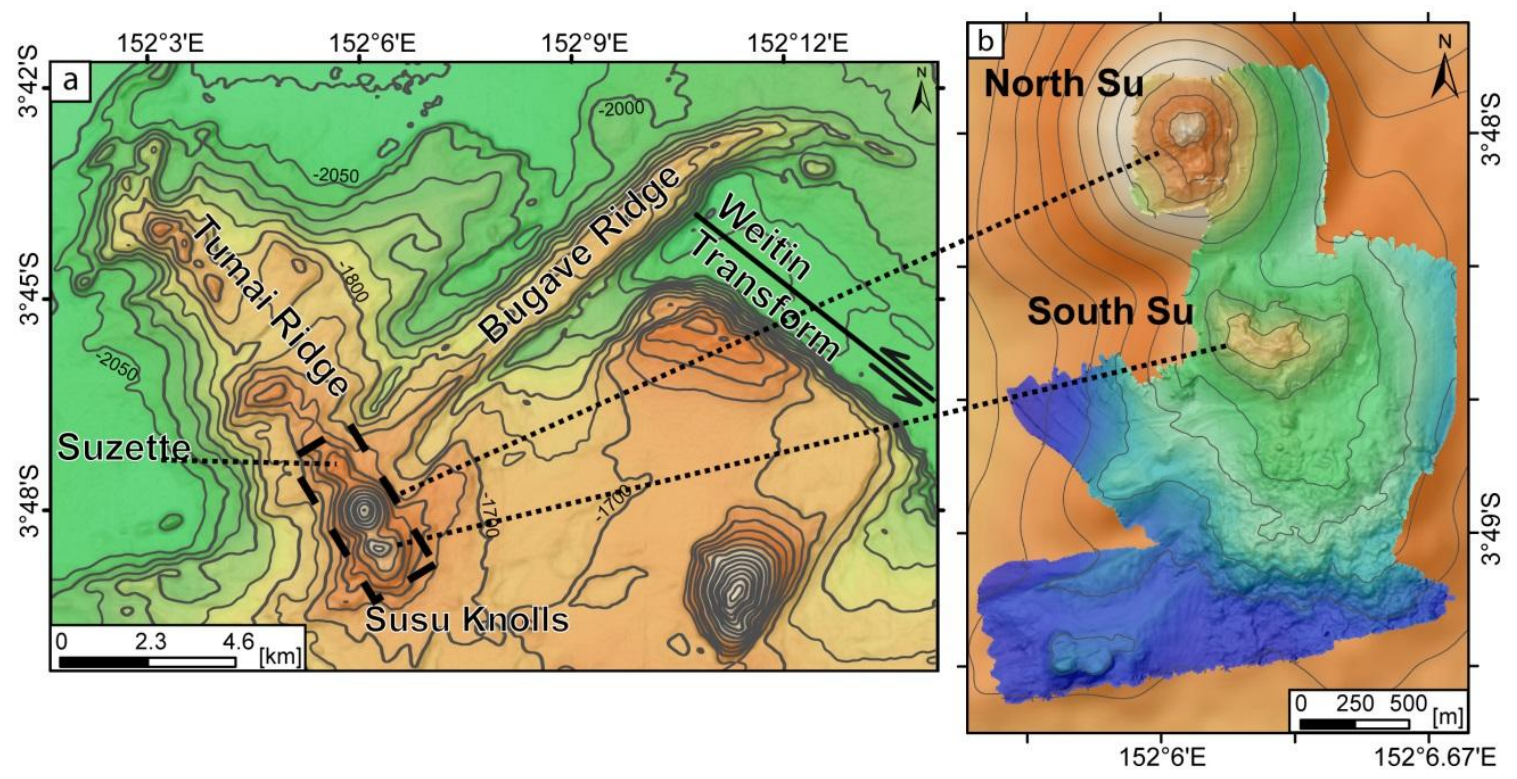

Fig.3: a) Ship-based bathymetry of SuSu Knolls with regional structures. Contour interval: $50 \mathrm{~m}$. Estimated position of Weitin Transform. b) Total coverage of AUV ABE bathymetry of North Su and South Su. $5 \mathrm{~m}$ grid. Contour interval $50 \mathrm{~m}$.

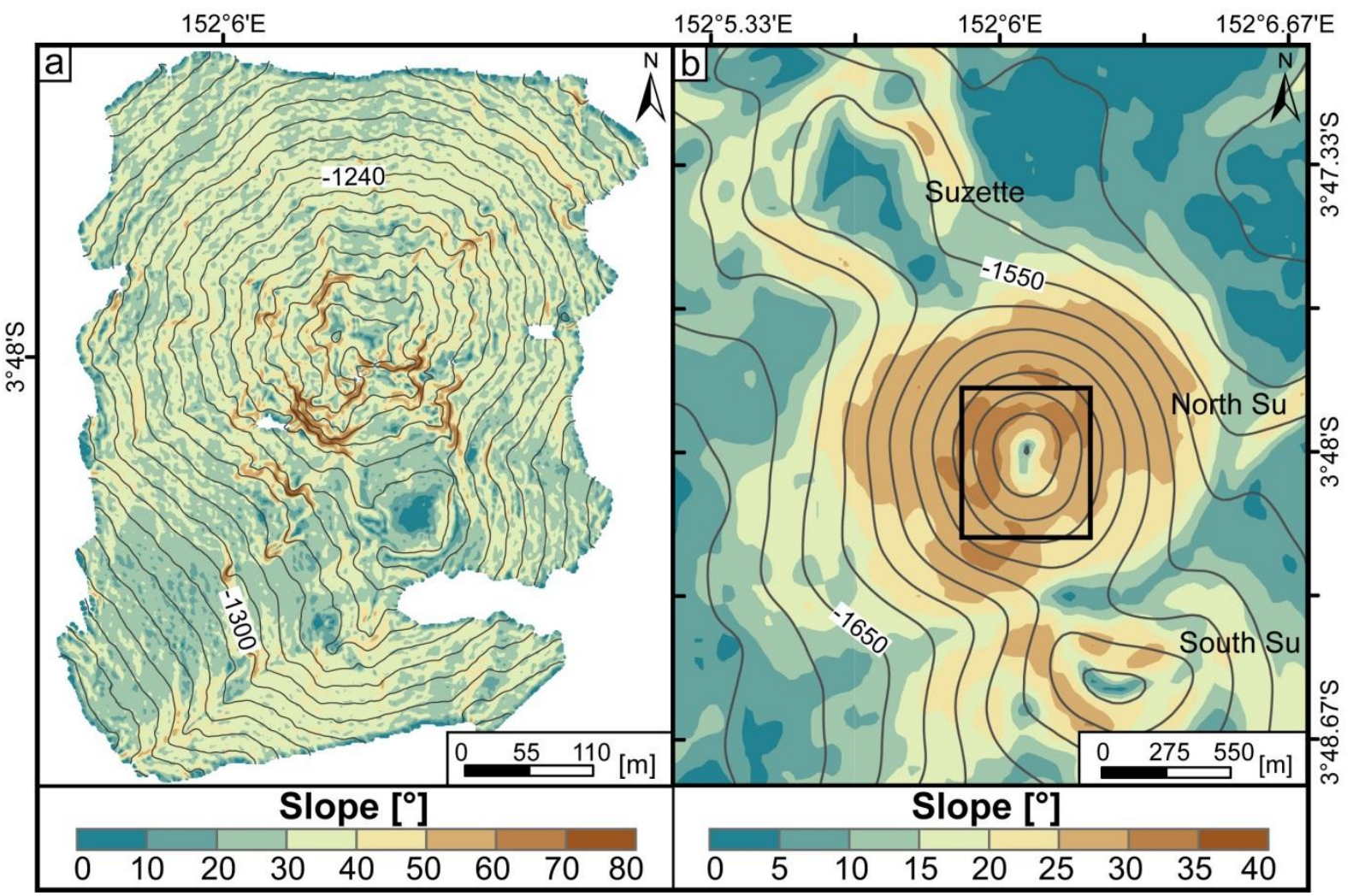

Fig. 4: SuSu Knolls morphology. a) 2006 - Slopemap of North Su with South Peak crater. It illustrates the cluster of cliffs on the southern slope of North Peak. AUV ABE $1 \mathrm{~m}$ grid; b) 2011 - Slopemap of SuSu Knolls revealing the mean slope on North Su to be $25-30^{\circ}$ with steeper slope around the summit areas. Filtered ship-based bathymetry, $32 \mathrm{~m}$ grid. Black rectangle marks position of a). 


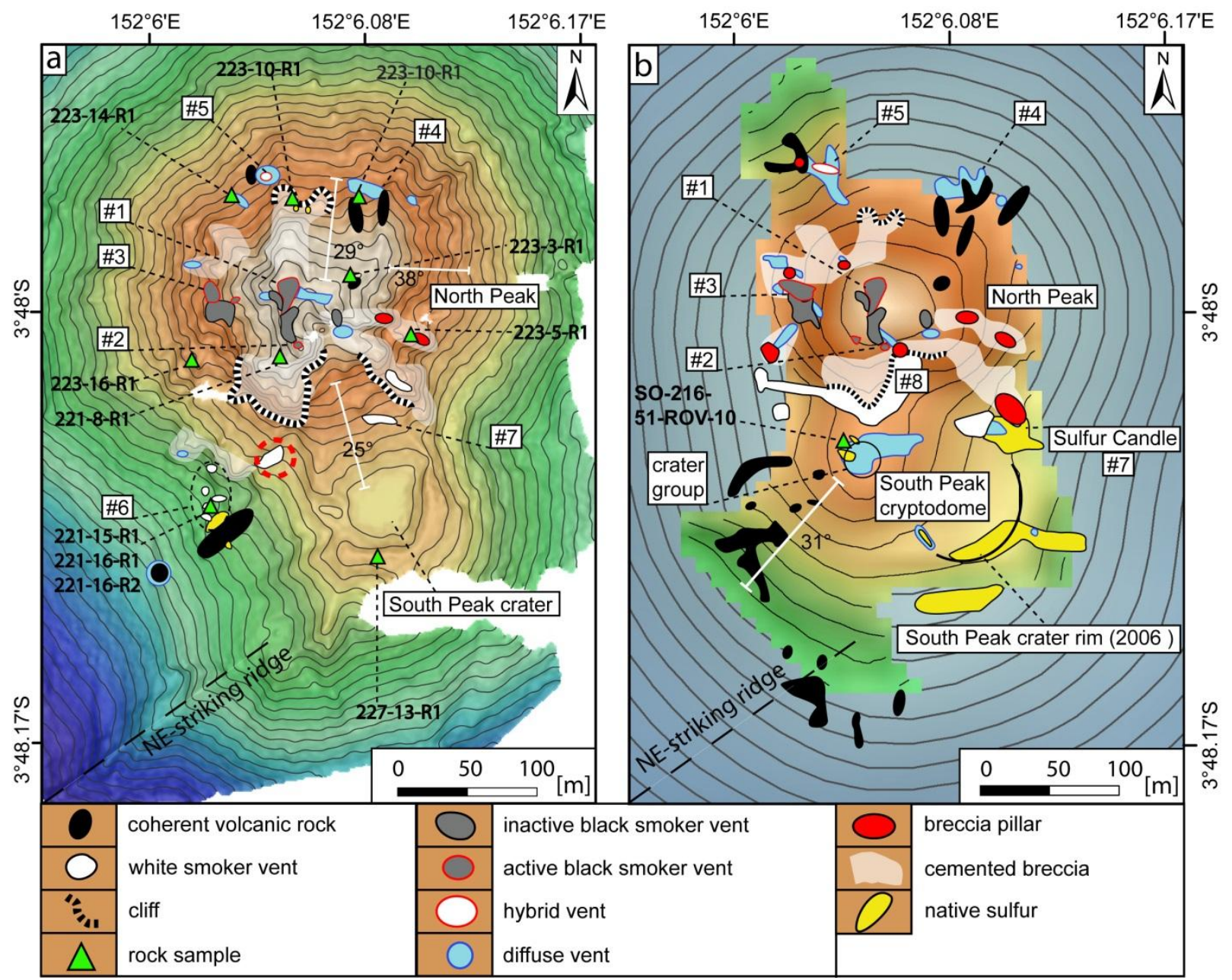

Fig. 5: a) Geologic map from 2006 on ABE bathymetry ( $1 \mathrm{~m}$ grid spacing) with $5 \mathrm{~m}$ contours; dotted red circle indicates the location of the crater group mapped in 2011. b) Geologic map from 2011 on ROV Quest bathymetry (10 m grid spacing) and EM120 bathymetry in the background (32 m grid spacing) with $10 \mathrm{~m}$ contours. White bars mark the track for which a mean slope is calculated that is posted next to the bar. 

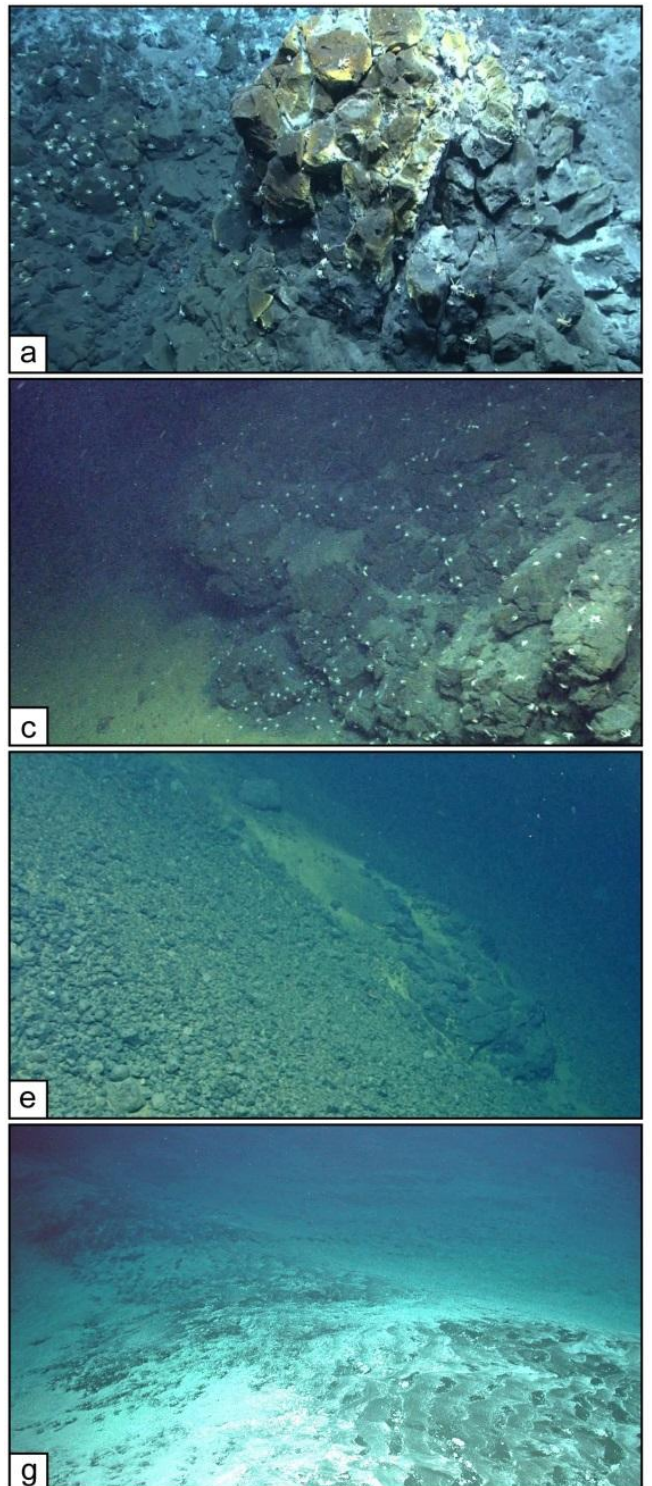

g
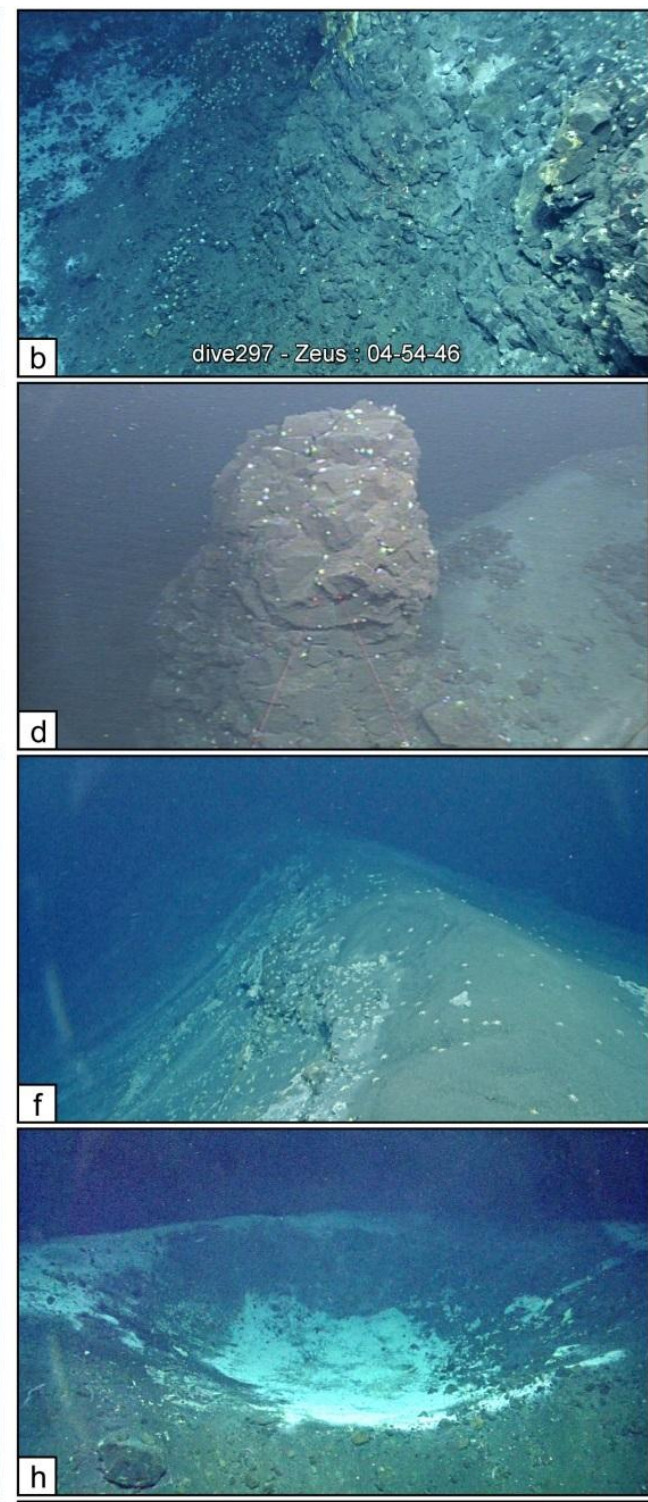

Fig. 6: Observed volcanic morphologies, lithologies and features. Picture widths of structures in the foreground are given in brackets. a) Fissured, jig-saw-fit outcrop. The broken pieces are still in place, NE North Peak $(\sim 1 \mathrm{~m})$; b) Downward looking perspective on a vertical lava outcrop, fissured and blocky, NE North Peak ( $3 \mathrm{~m})$; c) Short $(<5 \mathrm{~m})$, columnar, fractured lava flow, SW South Peak cryptodome (2-3 m); d) Lava spine, North Peak ( 2 m); e) Lava lobe breaching through the scree covered slope, SW South Peak cryptodome (2-3 m); f) View towards NE along the crater rim of South Peak crater in 2011. The crater centre is to the left $(\sim 1 \mathrm{~m}) ; \mathrm{g})$ Plateau on South Peak with stream ripples $(\sim 1.5 \mathrm{~m})$; h) A crater of crater group on South Peak cryptodome. The crater diameter is about $4-5 \mathrm{~m}$ and $<1 \mathrm{~m}$ deep. 


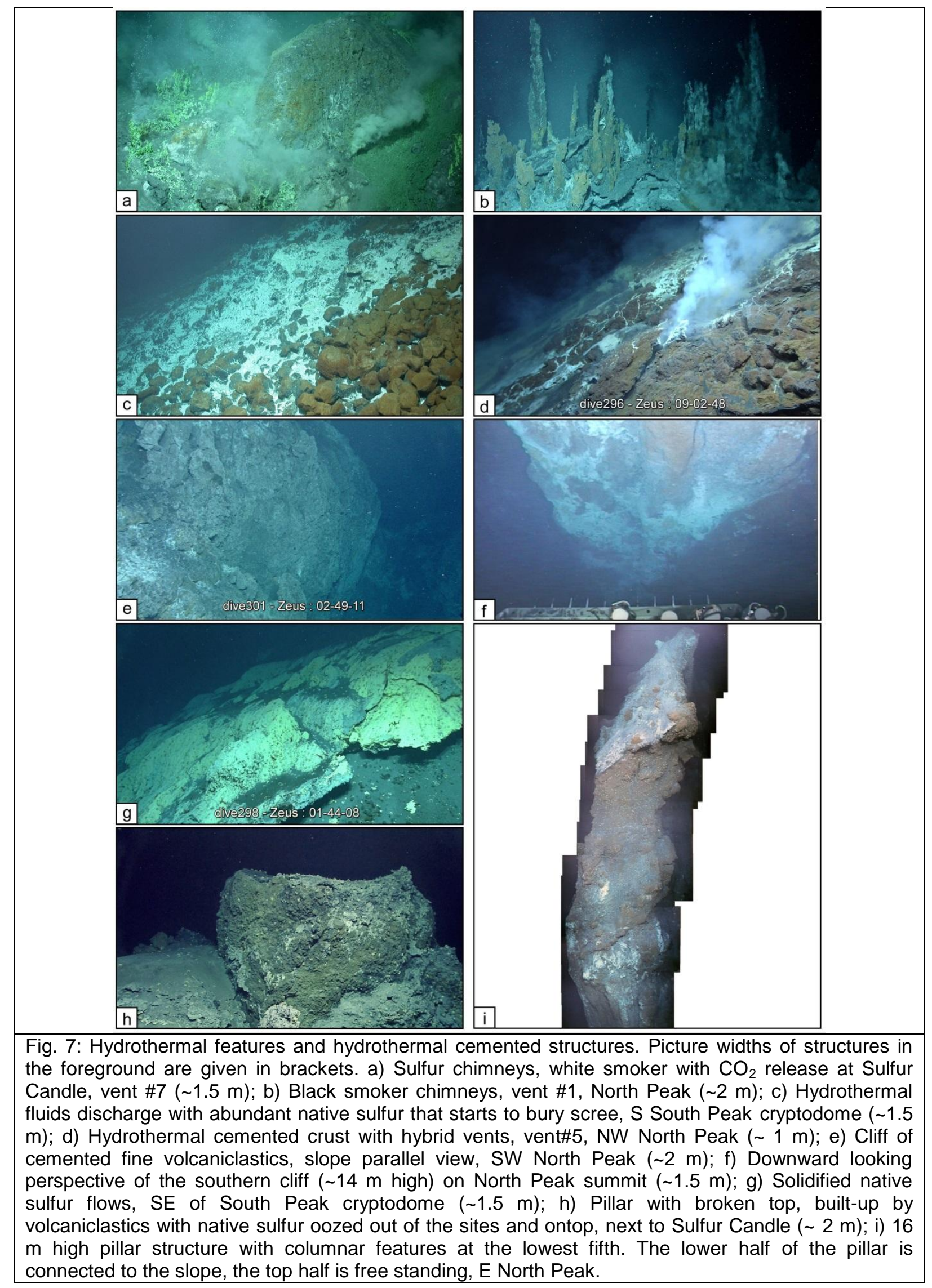




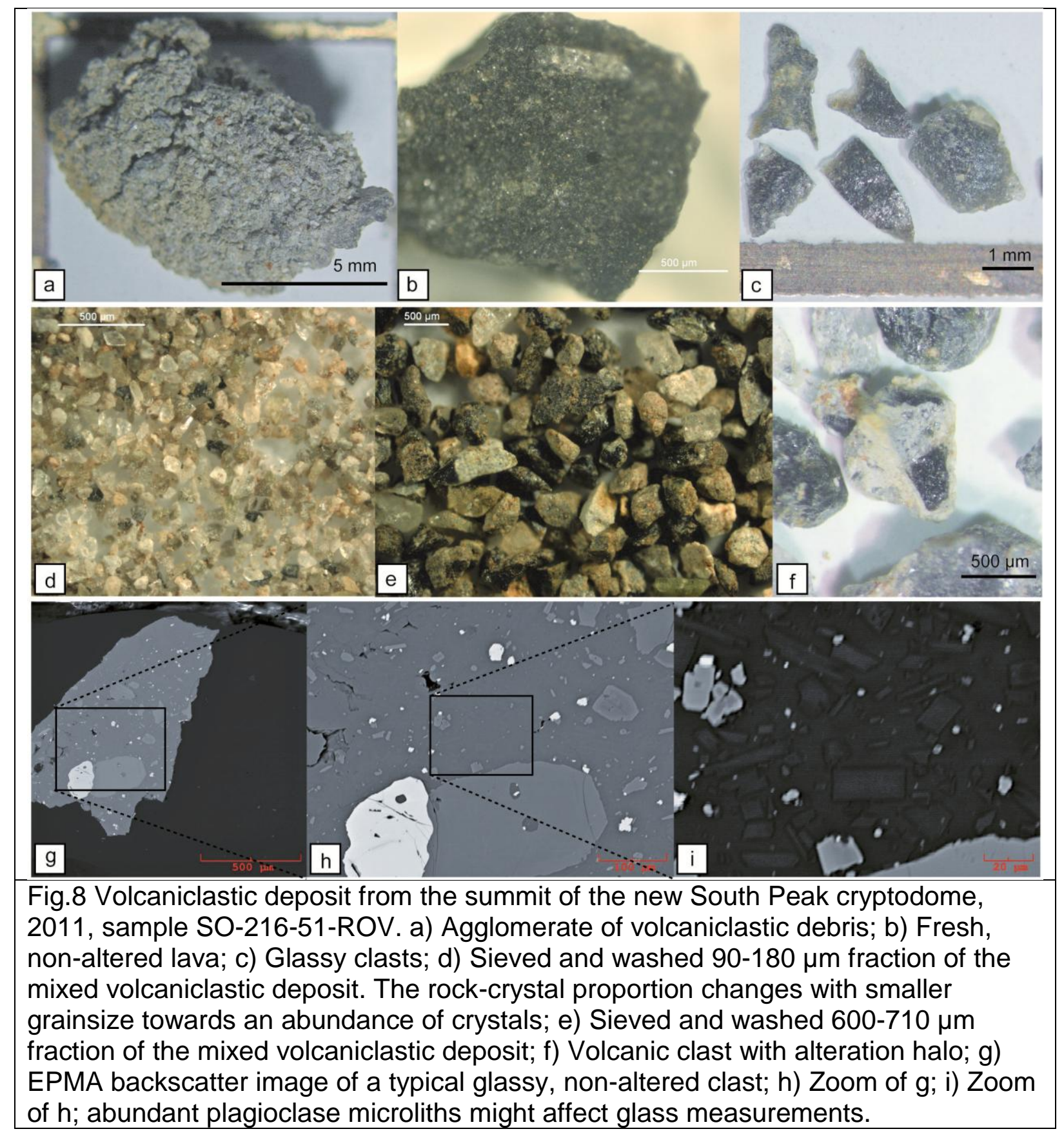




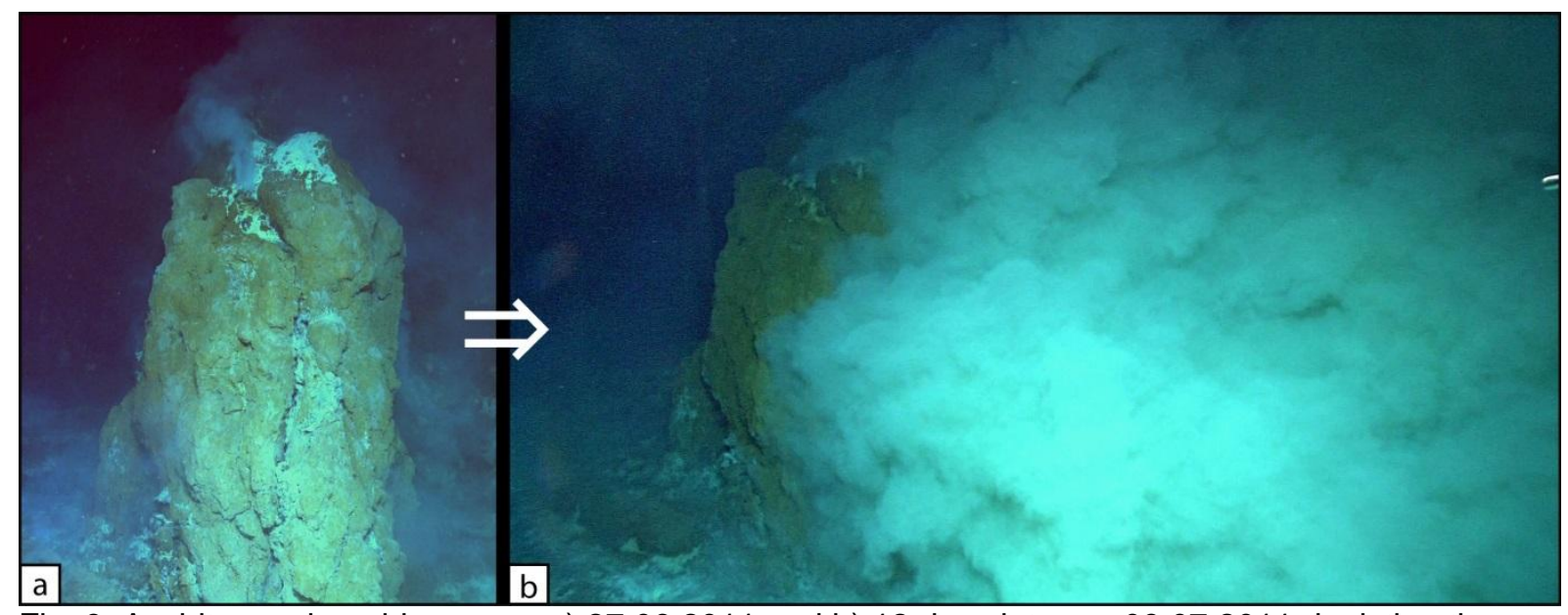

Fig. 9: A white smoker chimney on a) 27.06.2011 and b) 12 days later on 09.07.2011 depicting the pulsating nature of the white smoker hydrothermal system.
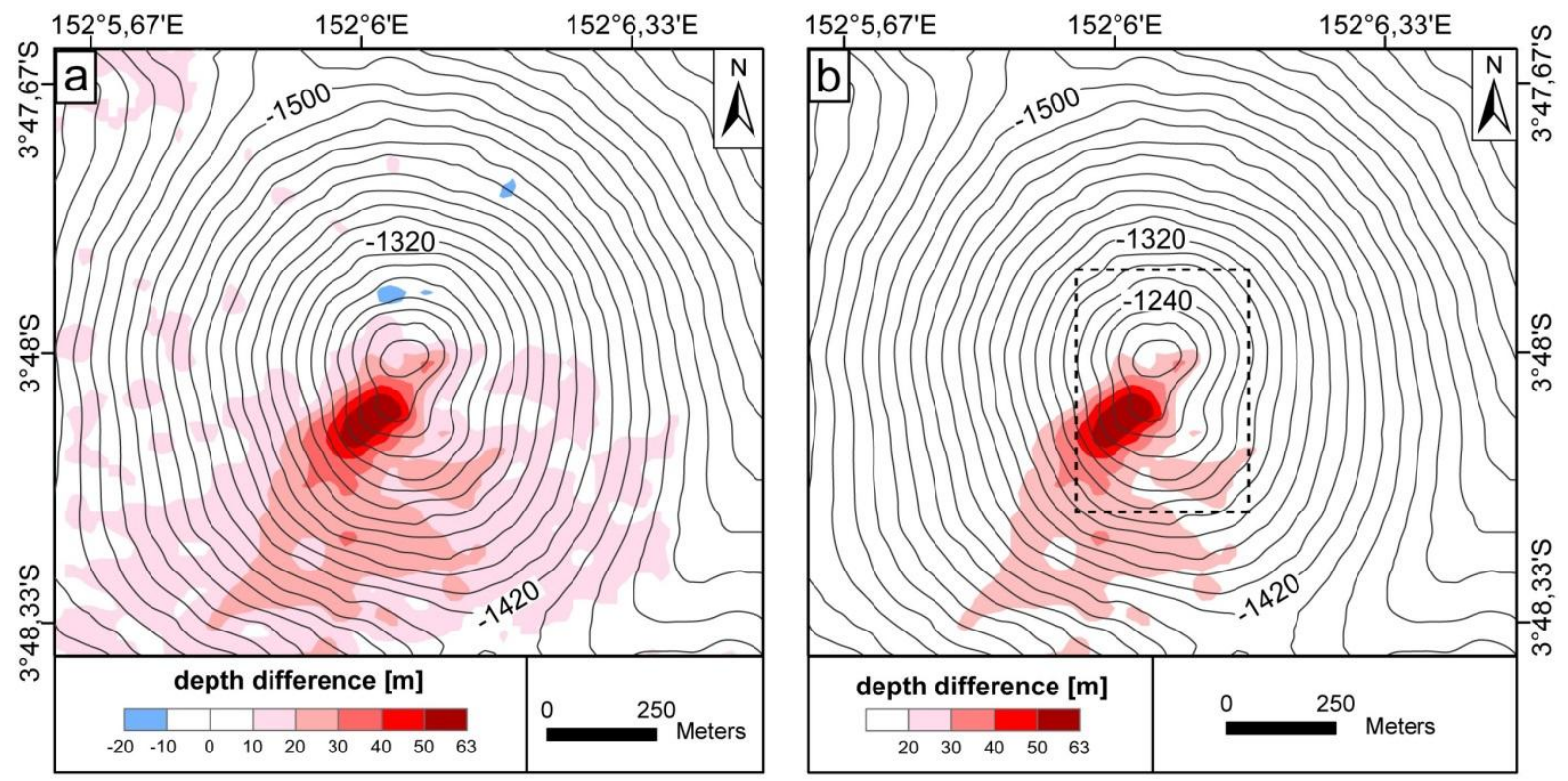

Fig. 10: Results from SO-166 (2002) and SO-216 (2011) ship-based bathymetry comparison.

Contours are from SO-216 bathymetry with interval of $20 \mathrm{~m}$. Red color indicates positive depth change and blue indicates negative. a) Depth differences $>10 \mathrm{~m} \mathrm{~b}$ ) Depth differences $>20 \mathrm{~m}$. Dotted rectangle indicates extend of maps in Figure 7. 

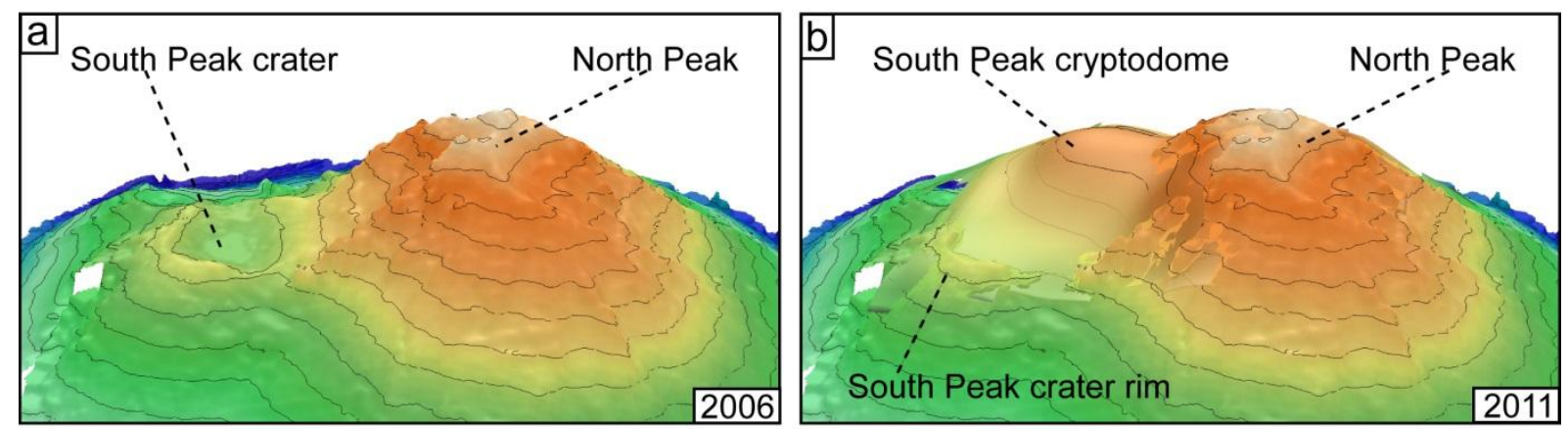

Fig. 11: Oblique perspectives on North Su from NE. a) AUV ABE bathymetry showing North Peak and South Peak crater in 2006; b) Same perspective view as a) with additional ROV Quest bathymetry (2011) depicting the growth of South Peak by the cryptodome emplacement.
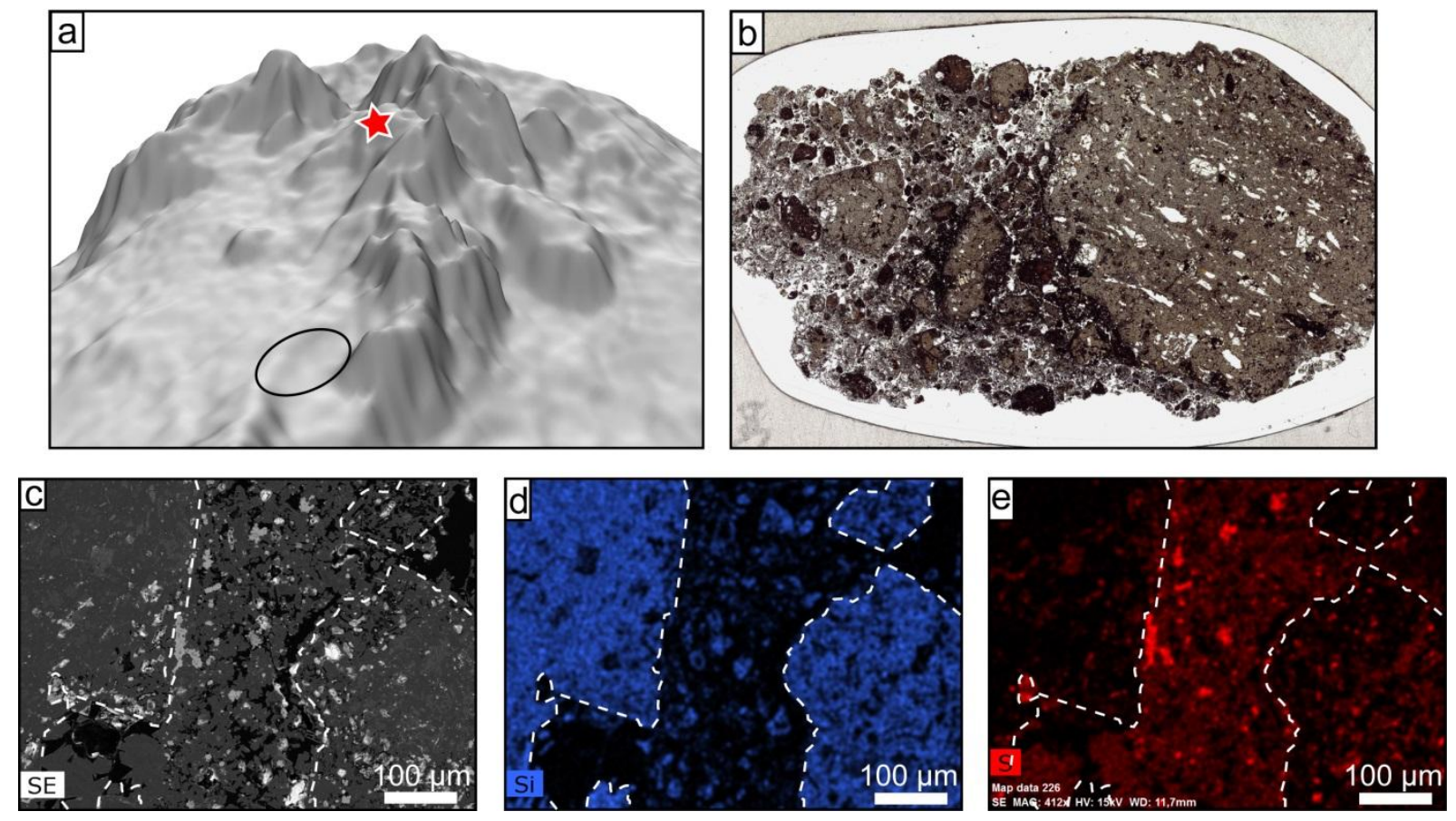

Figure 12: Hydrothermally cemented breccias temporarily increase the local slope stability. These breccias form pillars, ridgelines and cliffs when the surrounding slope collapses. a) Oblique perspective from South-East on the southern slope of North Peak. The red star in a indicates sample location for b. Black circle marks the position of Sulfur Candle site. b) Thinsection of a cemented breccia taken from a cliff. Single clasts are clearly visible within a greyish matrix. Picture width is 3.5 $\mathrm{cm}$. Sample J2-223-6-R1. c - e) Raster electron microscopy images of the thinsection shown in b. Lithic clasts are highlighted with white outlines. c) Secondary electron image. d) Element map of Si depicting the shape of volcanic clasts. e) Element map of $S$ illustrates the hydrothermal cement filling void space between clasts. 

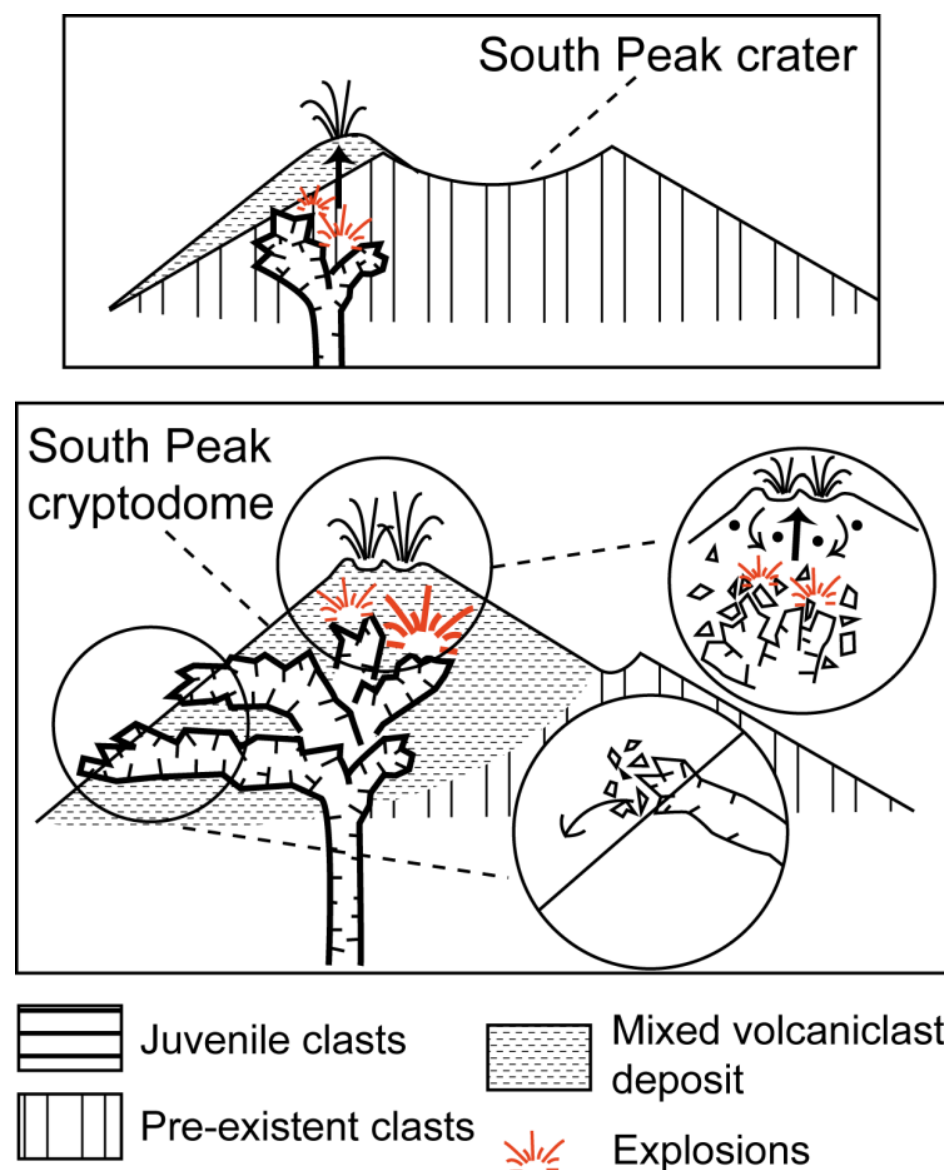

Juvenile clasts

Pre-existent clasts

Mixed volcaniclastic

deposit

$\sqrt[V]{ }$, Ejected material

Fig. 13: Simplified sketch explaining the observed morphologic and volcanic features at the South Peak cryptodome eruption. a) High viscous magma intrudes into the water-saturated volcaniclastic governed slope of North Su. Non-explosive fragmentation, explosive degassing and hydrovolcanic explosions disrupt the pre-existend material and the erupting lava which fails as a brittle solid due to its high crystal content and semi-solid state, causing dominantly blocky clasts that mix with the preexisting material of North Su. b) The magma erupts as single lobes that occasionally breach through that clastic cover which than suffer from further fragmentation resulting in blocky outcrops. Explosions accompany the eruption produce clast-laden steam jets that thrust through the clastic cover and emit mixed volcaniclastic material onto the seafloor. This process creates a group of small, randomly scattered, shallow craters. Due to updoming and enhanced by several explosion, clasts are reworked which is expressed by a relatively rounded shape. 


\begin{tabular}{|c|c|c|c|c|c|c|c|c|c|c|c|}
\hline \multirow[b]{3}{*}{ w } & \multicolumn{11}{|c|}{ Sample \# } \\
\hline & \multicolumn{4}{|c|}{ J2-221- } & \multicolumn{6}{|c|}{ J2-223- } & \multirow{2}{*}{\begin{tabular}{|l|} 
J2-227- \\
13-R1
\end{tabular}} \\
\hline & 8-R1 & $\begin{array}{l}\text { 15- } \\
\text { R1 }\end{array}$ & $\begin{array}{l}\text { 16- } \\
\text { R1 } \\
\end{array}$ & 16-R2 & 3-R1 & 5-R1 & 9-R2 & 10-R1 & $\begin{array}{l}\text { 14- } \\
\text { R1 }\end{array}$ & $\begin{array}{l}\text { 16- } \\
\text { R1 }\end{array}$ & \\
\hline $\mathrm{SiO2}$ & 59.59 & 60.46 & 61.39 & 60.07 & 61.21 & 61.34 & 60.86 & 61.54 & 62.16 & 62.52 & 63.73 \\
\hline TiO2 & 0.54 & 0.56 & 0.56 & 0.55 & 0.57 & 0.57 & 0.56 & 0.58 & 0.58 & 0.57 & 0.56 \\
\hline $\mathrm{Al}_{2} \mathrm{O}_{3}$ & 13.95 & 14.69 & 14.69 & 14.36 & 14.90 & 14.69 & 14.83 & 14.78 & 14.97 & 14.85 & 14.76 \\
\hline $\mathrm{Fe}_{2} \mathrm{O}_{3}$ & 6.94 & 6.60 & 5.85 & 7.17 & 7.34 & 6.29 & 7.06 & 7.15 & 6.59 & 6.36 & 4.39 \\
\hline MnO & 0.130 & 0.127 & 0.120 & 0.138 & 0.152 & 0.120 & 0.131 & 0.132 & 0.128 & 0.122 & 0.086 \\
\hline MgO & 4.09 & 2.81 & 2.61 & 4.20 & 3.08 & 2.25 & 3.08 & 2.60 & 2.75 & 2.32 & 2.16 \\
\hline $\mathrm{CaO}$ & 6.48 & 5.96 & 5.81 & 7.05 & 6.44 & 5.78 & 6.43 & 5.90 & 6.12 & 5.50 & 5.21 \\
\hline $\mathrm{Na}_{2} \mathrm{O}$ & 2.94 & 3.60 & 2.69 & 3.40 & 3.73 & 4.41 & 3.65 & 3.82 & 3.77 & 3.90 & 3.95 \\
\hline $\mathrm{K}_{2} \mathrm{O}$ & 0.78 & 0.98 & 0.80 & 0.87 & 0.98 & 1.12 & 0.97 & 1.03 & 1.01 & 1.08 & 0.88 \\
\hline $\mathrm{P}_{2} \mathrm{O}_{5}$ & 0.17 & 0.15 & 0.13 & 0.17 & 0.21 & 0.19 & 0.19 & 0.20 & 0.19 & 0.19 & 0.09 \\
\hline $\mathrm{H}_{2} \mathrm{O}$ & 2.65 & 1.55 & 3.33 & 1.17 & 0.97 & 1.41 & 1.28 & 1.02 & 1.06 & 1.26 & 1.41 \\
\hline $\mathrm{CO}_{2}$ & 0.02 & 0.03 & 0.04 & 0.02 & 0.03 & 0.04 & 0.06 & 0.06 & 0.03 & 0.03 & 0.03 \\
\hline Total & 98.35 & 97.60 & 98.10 & 99.17 & 99.62 & 98.20 & 99.10 & 98.80 & 99.35 & 98.70 & 97.33 \\
\hline
\end{tabular}

Table A1: Results of whole rock XRF analyses. All iron measured as $\mathrm{Fe}_{2} \mathrm{O}_{3}$.

\begin{tabular}{|c|c|c|c|c|c|c|}
\hline \multirow[b]{3}{*}{ wt. \% } & \multicolumn{6}{|c|}{ Sample \# } \\
\hline & \multicolumn{2}{|c|}{ J2-221- } & \multicolumn{4}{|c|}{ J2-223- } \\
\hline & 8-r1 & 16-r1 & 5-R1 & $9-r 2$ & 10-R1 & 14-r1 \\
\hline $\mathrm{SiO}_{2}$ & 66,87 & 68,18 & 74,11 & 72,90 & 74,45 & 73,51 \\
\hline $\mathrm{TiO}_{2}$ & 0,61 & 0,62 & 0,56 & 0,49 & 0,49 & 0,56 \\
\hline $\mathrm{Al}_{2} \mathrm{O}_{3}$ & 13,40 & 13,28 & 12,60 & 12,75 & 12,39 & 12,64 \\
\hline $\mathrm{Cr}_{2} \mathrm{O}_{3}$ & 0,000 & 0,000 & 0,010 & 0,000 & 0,017 & 0,017 \\
\hline $\mathrm{FeO}$ & 5,67 & 5,54 & 3,48 & 2,76 & 3,48 & 3,09 \\
\hline MnO & 0,12 & 0,13 & 0,09 & 0,10 & 0,08 & 0,06 \\
\hline MgO & 1,32 & 1,18 & 0,38 & 0,23 & 0,43 & 0,24 \\
\hline $\mathrm{CaO}$ & 3,99 & 3,85 & 2,06 & 2,13 & 2,02 & 2,04 \\
\hline $\mathrm{Na}_{2} \mathrm{O}$ & 3,53 & 3,65 & 4,35 & 3,64 & 4,41 & 4,43 \\
\hline $\mathrm{K}_{2} \mathrm{O}$ & 1,42 & 1,50 & 1,92 & 1,71 & 1,95 & 1,85 \\
\hline $\mathrm{P}_{2} \mathrm{O}_{5}$ & 0,29 & 0,30 & 0,13 & 0,10 & 0,21 & 0,12 \\
\hline $\mathrm{SO}_{3}$ & 0,02 & 0,01 & 0,00 & 0,00 & 0,00 & 0,00 \\
\hline $\mathrm{BaO}$ & 0,00 & 0,00 & 0,08 & 0,00 & 0,07 & 0,00 \\
\hline $\mathrm{Cl}$ & 0,22 & 0,22 & 0,26 & 0,26 & 0,26 & 0,27 \\
\hline Total & 97,46 & 98,46 & 99,93 & 97,06 & 100,17 & 98,82 \\
\hline
\end{tabular}

Table A2: Glass analyses measured with EPMA. 


\begin{tabular}{|c|l|c|c|c|c|c|}
\hline Vent \# & \multicolumn{1}{|c|}{ Fluid type } & Year & Water depth [m] & Temperature $\left.{ }^{\circ} \mathbf{C}\right]$ & Lat & Lon \\
\hline $\mathbf{1}$ & Black Smoker & 2006 & 1158 & 298 & 152.1009 & -3.7999 \\
& & 2011 & 1154 & 314 & & \\
\hline $\mathbf{2}$ & Black Smoker & 2006 & 1157 & 300 & 152.1009 & -3.8002 \\
\hline $\mathbf{3}$ & Black Smoker & 2006 & 1194 & 324 & 152.1004 & -3.7999 \\
& & 2011 & 1192 & 332 & 152.1003 & -3.7998 \\
\hline $\mathbf{4}$ & Diffuse venting & 2006 & 1196 & 32 & 152.1014 & -3.7993 \\
& & 2011 & & 44 & & \\
\hline $\mathbf{5}$ & Hybrid vents & 2006 & 1207 & 240 & 152.1008 & -3.7991 \\
& & 2011 & 1228 & 169 & 152.1005 & -3.799 \\
\hline $\mathbf{6}$ & White Smoker & 2006 & 1263 & 284 & 152.1005 & -3.8012 \\
\hline $\mathbf{7}$ & White Smoker & 2006 & 1217 & 71 & 152.1015 & -3.8006 \\
& & 2011 & 1220 & 104 & 152.1015 & -3.8006 \\
\hline $\mathbf{8}$ & White Smoker & 2011 & 1202 & 79 & 152.1005 & -3.8006 \\
\hline
\end{tabular}

Table A3: List of hydrothermal vents at North Su with positions of temperature measurements, year and water depth. 